\title{
Venture Capital and Other Private Equity: a Survey
}

\section{Andrew Metrick}

Yale School of Management, 135 Prospect Street, New Haven, CT 06520, USA; NBER

E-mail:metrick@yale.edu

\section{Ayako Yasuda}

UC Davis, Graduate School of Management, 3206 Gallagher Hall, Davis, CA 95616-8609, USA E-mail: asyasuda@ucdavis.edu

\begin{abstract}
We review the theory and evidence on venture capital (VC) and other private equity: why professional private equity exists, what private equity managers do with their portfolio companies, what returns they earn, who earns more and why, what determines the design of contracts signed between (i) private equity managers and their portfolio companies and (ii) private equity managers and their investors (limited partners), and how/whether these contractual designs affect outcomes. Findings highlight the importance of private ownership, and information asymmetry and illiquidity associated with it, as a key explanatory factor of what makes private equity different from other asset classes.
\end{abstract}

Keywords: private equity, venture capital, buyouts, alternative assets

JEL Classification: $G 2, G 3, G 24, G 32, G 34$

\section{Introduction}

Worldwide, private equity funds manage about $\$ 2.5$ trillion (TheCityUK 2010, p. 2). While buyouts (BO) generally account for one-half to two-thirds of private equity investments by value, venture capital (VC) accounts for the majority of investments by number of deals. The industry underwent an extraordinary growth in the last 15 years, increasing from $\$ 100$ billion in 1994 (Fenn and Liang 1998, p. 2). A main driver of this change was institutional investors' portfolio allocation to private equity, which increased from 3\% (2\%) on average in 1997 to $12 \%(6 \%)$ in 2007 for large foundations (endowments). ${ }^{1}$ Private equity funds' roles in the economy and their managerial compensation drew scrutiny among policymakers in the aftermath of the

We thank John Doukas (editor) and an anonymous referee for helpful comments and suggestions. All errors and omissions are our own.

${ }^{1}$ Cambridge Associates estimates. 
2007-8 financial crisis, and there is an ongoing debate about increasing taxation on private equity managers' profit participation (= 'carried interest'), and on the industry's impact on innovation, competition, and employment. The industry has rapidly globalised in recent years, with China receiving the third highest investment after the USA and UK in 2008-2009, followed by France and India. ${ }^{2}$ Reflecting their increasingly important roles as financial intermediaries and as activist investors, the literature studying venture capital and other private equity (e.g., buyouts) funds has grown significantly in the last decade.

In this paper we review the literature on the following topics: why professional private equity exists; what private equity managers do with their portfolio companies; what returns they earn, who earns more and why; what determines the design of contracts signed between (i) them and portfolio companies and (ii) them and their investors (limited partners); and how/whether these contractual designs affect outcomes.

To the best of our knowledge this is the only survey paper that treats both the venture capital (VC) and the buyout (BO) segments as subsets of a broader, private equity industry. By doing so, we highlight similarities among them - what makes them both 'private equity' - in contrast to the public equity markets. The key defining characteristics are the illiquidity of the capital and the information asymmetry between insiders and outsiders of the firms. Often times, the focus in the literature is on 'leveraged' in the 'leveraged buyouts' - even though an LBO is just one of many deal structures that private equity investors employ to deploy their fund capital. We instead focus on what distinguishes both the venture capital and buyout funds from other investment management vehicles, such as hedge funds and mutual funds, and discuss the theory and evidence on this 'private equity' industry both as financial intermediaries and as an asset class. ${ }^{3}$

We begin in Section 2 by defining private equity and then discussing theories that motivate the existence and economic rationale for venture capital and buyout specialists, respectively. Both VCs and BO investors are financial intermediaries that raise funds from institutional investors and invest in private, illiquid companies. They are both activist investors that exercise significant control rights over their portfolio companies, and aim to maximise financial returns on behalf of their investors. Theories explaining the rationale for $\mathrm{VC}$ emphasise the information asymmetry between entrepreneurs and investors and contrast VCs' superior information production ability vis-à-vis banks. Theories explaining the rationale for $\mathrm{BO}$ instead assume that $\mathrm{BO}$ targets are public firms and either highlight the improved managerial incentives of LBO firms (as compared with those given to public company CEOs) or are concerned more broadly with the question of why firms go private. Neither strand of theories explains why private firms become targets of $\mathrm{BO}$ funds.

Section 3 reviews the broad literature that documents the economic (value-added) activities of $\mathrm{VC}$ and $\mathrm{BO}$ investors. The literature identifies three groups of economic

\footnotetext{
${ }^{2}$ TheCityUK (2010, p.1, Table 1).

${ }^{3}$ For survey papers focusing on venture capital, see, for example, Fenn and Liang (1998), Gompers and Lerner (2001), and Denis (2004), and more recently, Kaplan and Lerner (2010) and Krishnan and Masulis (forthcoming); for survey papers focusing on buyouts, see, among others, Cumming et al. (2007) and Kaplan and Stromberg (2009). For a broader survey on financial intermediation that includes private equity, see Chemmanur (forthcoming). Also see Lerner (forthcoming).
} 
activities for both VC and BO, namely: (1) pre-investment screening activities; (2) monitoring / governance activities during the holding period; and (3) influencing and orchestrating exiting activities.

In Section 4 we focus on the performance of the private equity funds. We begin by discussing the levels of risk-adjusted returns. We then review the evidence on performance persistence, and various sources of both the level of excess performance and its persistence. The extant evidence on excess performance (and its persistence) in private equity is mixed; we provide several reasons as to why this is and suggest future areas for research.

In Section 5, we discuss the strand of literature that examines features of contracts signed between private equity fund managers and their investors, as well as contracts signed between private equity fund managers and their portfolio companies. Both VC and BO funds are organised as closed-end, finite-life limited partnerships, with fund managers serving as general partners (GPs) and investors as limited partners (LPs). Partnership agreements set management fees, carried interest, and (in case of BO funds) terms of transaction fees and monitoring fees. The agreements also restrict activities of the fund managers through various covenants. The literature on VC contracts has focused on the use of convertible securities, staged financing, syndication, voting rights, and board rights. In contrast to the extensive literature on the VC contracts, the theoretical literature on the $\mathrm{BO}$ contracts is almost nonexistent. Evidence from existing empirical analyses suggest that agency problems between GPs and LPs of BO funds may be exacerbated when cheap debt is available and allows GPs to collect large fees from portfolio companies upfront in the form of transaction fees.

Finally, in Section 6 we conclude with a summary of what we know and what still needs to be learned.

\section{Why Do Venture Capital and Private Equity Markets Exist?}

\subsection{What is private equity?}

We provide a definition of private equity funds by listing the following main characteristics:

1. A PE fund is a financial intermediary, meaning that it takes the investors' capital and invests it directly in portfolio companies.

2. A PE fund invests only in private companies. This means that once the investments are made, the companies cannot be immediately traded on a public exchange.

3. A PE fund takes an active role in monitoring and helping the companies in its portfolio.

4. A PE fund's primary goal is to maximise its financial return by exiting investments through a sale or an initial public offering (IPO).

Characteristic (1) defines PE funds as financial intermediaries and differentiates it from angel investors and private investment companies that use their own capital. Typically these funds are organised as limited partnerships, with the venture capitalists or the buyout firm partners acting as the general partners (GPs) of the fund and the investors - often pension funds, endowments and other institutional investors - acting as the limited partners (LPs). Potential agency conflicts between GPs and LPs are addressed 
ALTERNATIVE INVESTMENTS

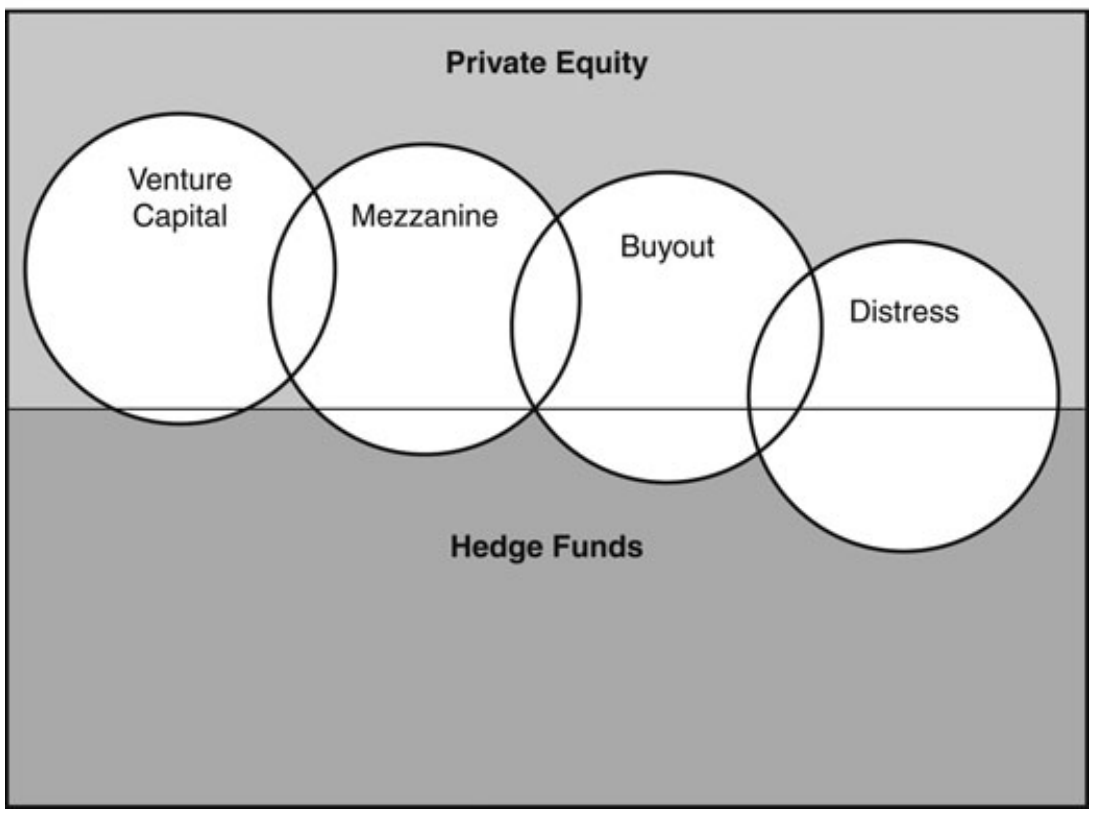

Fig. 1. Private equity and hedge funds.

This figure illustrates the overlapping structure of the four main types of private equity investing and also shows the intersection of these types with hedge funds, another category of alternative investment Source: (Metrick and Yasuda 2010b), Exhibit 1-2

by contractual provisions in the limited partnership agreements, and have been examined in the literature, as discussed below.

Characteristic (2) is the most obvious defining feature of private equity and distinguishes it from both the traditional investment assets of stocks and bonds as well as the other alternative asset of hedge funds. Figure 1 illustrates the relationship between various asset classes within private equity and also between private equity and other asset classes. Within private equity, there are four main subclasses, of which VC and BO are the largest and most important two. Overlapping circles in Figure 1 indicate where the scopes of neighbouring groups overlap: for example, the mezzanine category comprises both growth equity (that overlaps with later-stage venture capital) and the subordinate debt layer of buyout transactions (which is often attached to some equity ownership) and thus overlaps with both venture capital and buyouts. Distressed investing, on the other hand, can be thought of as a specialised segment of buyouts that target mature and distressed companies.

In all four cases, portfolio companies of private equity funds are private companies for which little public information exists. Thus, information asymmetry is thought to be far greater in private equity compared with investments in public companies that must file regular reports with the SEC and also are often covered by Wall Street analysts. As a result, portfolio values of private equity funds are not marked to market and fund returns are not finalised until the end of the funds' lifetime. In contrast, while some hedge funds participate in private equity transactions (especially larger companies that buyouts and 
distressed investors invest in), they are primarily investors in publicly traded assets such as stocks and bonds and their portfolios are marked to market.

Characteristic (3) is central to the raison d'être of private equity - and potentially a key determinant of a given PE fund's performance. While all 'active' investment fund managers - mutual funds, hedge funds, and private equity funds - select their stocks and are evaluated on their ability to pick winners, not all of them actively influence actions of the management of the companies they invest in. Except for large blockholders who gain seats on the boards of public companies, public company investors' ability to influence the management is severely limited. In contrast, private equity investors often condition their investments on contractual provisions, such as board seats, veto rights, and various contingent control rights, that enable them to influence the actions of the management while they hold their investments. In Section 3, we provide an extensive review of the literature's findings on these monitoring / value-adding activities performed by PE fund managers.

Finally, since PE funds are financial intermediaries, they need some mechanism to give money back to their investors, which gives rise to Characteristic (4). Exits can occur through an IPO, with a subsequent sale of the PE stake in the open market, through a sale of the company to another investor (especially to another BO fund), or through the sale of the company to a larger company. The requirement to exit and the focus on financial return differentiates $\mathrm{PE}$ from strategic investments done by large corporations. While corporations are active both in $\mathrm{VC}$ and $\mathrm{BO}$ markets, their investment criteria are different from professional PE because of the lack of need for exits and greater emphasis on synergy with their existing operations.

To summarise, PE funds differ from both mutual funds and hedge funds in that they invest in illiquid, private companies, and differ from corporations in that they are required to return money to investors within a finite investment horizon and thus need to focus on targets with a clear path to exits. These functional differences are reflected in the ways PE funds are organised, in contrast to hedge funds and mutual funds, and as described in Table 1. PE funds have a finite life - typically 10 years - and a fixed fund size that is determined at the time of the fund inception. Both hedge funds and mutual funds are open-ended and do not have a finite fund lifetime. Within the fund lifetime, investors in PE funds must commit to illiquidity of up to 10 years, unlike hedge funds and mutual funds, both of which allow redemptions on demand, subject to some waiting period.

Because of the illiquidity and the long-term nature of PE investments, reinvestments are not permitted or restricted to a modest fraction of the fund size; in contrast, hedge fund and mutual fund investors are offered options to automatically reinvest any dividends and distributions from funds on an on-going basis. PE fees are often highest first and decline in later years, because successful managers are expected to raise follow-on funds with new fee streams; hedge fund and mutual fund fees are flat percentages of assets under management, so that total fees would rise over time as assets grow. And finally, despite the common perception, hedge fund and PE fund carried interest are earned quite differently. In hedge funds, carry is a fixed percentage (usually $20 \%$ ) of the market value of the portfolio in excess of cost basis, and can be earned each year as long as the former exceeds the latter, subject to high watermarks. In contrast, carried interest in PE is earned only on realised basis - i.e., only if investments are exited and cumulative exit values exceed the contractually specified threshold amount. Since exits typically are concentrated in the latter half of the funds' life, PE managers often wait for many years before they earn any carry from their funds. 
Table 1

Comparison of typical VC/PE fund terms with those of hedge funds and mutual funds

This table presents a comparison of typical fund terms of venture capital and buyout funds with those of hedge funds and mutual funds. An "open-end" fund can issue and redeem shares at any time (subject to lockups and waiting periods in case of hedge funds). A "finite-life" fund is obligated to terminate and liquidate its holdings at a pre-specified date. Reinvestments refer to use of fund distributions in order to invest in new or existing portfolio companies/assets.

\begin{tabular}{|c|c|c|c|}
\hline & \multicolumn{3}{|c|}{ Category } \\
\hline & $\mathrm{VC} / \mathrm{PE}$ find & Hedge Fund & Mutual Fund \\
\hline Open-end? & No & Yes & Varies \\
\hline Finite life? & Yes (10 years) & No & No \\
\hline $\begin{array}{l}\text { Liquidity/Capital } \\
\text { withdrawal } \\
\text { restrictions }\end{array}$ & $\begin{array}{l}\text { Illiquidity for up to } \\
10 \text { years }\end{array}$ & $\begin{array}{l}\text { Varies, e.g., } 1 \text { year } \\
\text { lockup and } 3 \\
\text { months wait } \\
\text { period for } \\
\text { withdrawals }\end{array}$ & $\begin{array}{l}\text { Minimal lockup and } \\
\text { redemption } \\
\text { restrictions }\end{array}$ \\
\hline Reinvestments & No & Yes & Yes \\
\hline Annual fees & $\begin{array}{l}\text { Effective } \% \text { often } \\
\text { varies over } \\
\text { lifetime of fund }\end{array}$ & $\begin{array}{l}\text { flat } \% \text { of asset under } \\
\text { management }\end{array}$ & $\begin{array}{l}\text { flat } \% \text { of asset under } \\
\text { management }\end{array}$ \\
\hline $\begin{array}{l}\text { Carry (Performance } \\
\text { fees) }\end{array}$ & $\begin{array}{l}\text { (usually) } 20 \% \text { of } \\
\text { realized profit, } \\
\text { payable only after } \\
\text { investment exits } \\
\text { and return of } \\
\text { capital to investors }\end{array}$ & $\begin{array}{l}\text { (usually) } 20 \% \text { of } \\
\text { annual implied } \\
\text { profit, payable as } \\
\text { long as market } \\
\text { value exceeds cost } \\
\text { ("high } \\
\text { watermarks") }\end{array}$ & usually none \\
\hline
\end{tabular}

\subsection{The economic rationale for professional venture capitalists}

Several theoretical papers offer economic rationale for existence of VC funds as defined above. (Chan, 1983) shows that, in a market setting with imperfect information and positive search costs, uninformed investors and informed entrepreneurs in equilibrium are unable to overcome the lemons problem and investors earn lower returns by investing in alternative projects. Venture capitalists as financial intermediaries may evolve as informed screening agents that improve the allocation of resources and welfare of the investors. (Campello and Da Matta, 2010) provide an equilibrium analysis of prospective LPs' demand for GPs' service, quality of GPs' screening activities, and payoffs GPs derive from running $\mathrm{VC}$ funds.

Venture capital funds are not the only financial intermediaries that bridge between investors and small businesses; banks also provide the intermediary function for small businesses. Ueda (2004) offers an explanation for why VCs and banks coexist in an economy. The key trade-off between the two choices is that while VCs' evaluations of the project quality are more accurate, they also use the threat of expropriation to extract rent from the entrepreneurs. The model explains why projects financed by VCs have less collateral, high growth, high risk, and high profitability, and why VC markets are more active in markets where intellectual property is better protected. 
Winton and Yerramilli (2008) is another paper that compares venture capital financing with bank financing. While Ueda (2004) focuses on the ex ante screening ability differential between VCs and banks, Winton and Yerramilli (2008) model follow-on financing decisions, thus incorporating ex post (costly) monitoring into their analysis. In addition to the standard continue-or-liquidate decision, the model allows for an aggressive or a conservative continuation choice, which makes continuation strategy risky in the sense of cash flow volatility between the two choices. VCs have better ability to monitor, but demand higher returns because they impose illiquidity on their investors; in contrast, banks are less skilled at monitoring, but demand lower returns from entrepreneurs because they themselves face lower funding cost by exposing themselves to liquidity shocks. VCs are optimal only if firms face highly risky and positively skewed project cash flows, with low probability of success, low liquidation value, and high returns if successful, and if they face highly volatile cash flows across two continuation strategies.

\subsection{The economic rationale for professional buyout investors}

The extant literature that relates to the economic rationale for existence of buyout investors has focused exclusively on public-to-private transactions, where formerly publicly traded companies are taken over by buyout investors and delisted. In one strand, the agency conflicts between shareholders and the management of public firms are emphasised, with leveraged buyouts proposed as solutions. In another strand of this literature, information and liquidity are emphasised as main factors governing the firm's decision to go private.

2.3.1 Jensen's theory of leveraged buyouts as governance mechanism. In a series of articles (e.g., Jensen and Meckling (1976); and Jensen (1986, 1989, 2007)), Jensen and his co-author advance a hypothesis that free cash flows in public firms present serious agency problems and that LBOs mitigate these conflicts between managers and shareholders. Private benefits of control (and higher compensation associated with larger firm size) induce public firm mangers to engage in empire building and misuse free cash flows, both at the expense of shareholders. Jensen argues that debt reduces agency costs of free cash flows and disciplines the managers, and that the growth in popularity of LBOs during the 1980's was partly due to this control function of debt. Moreover, larger managerial ownership and the monitoring and controlling functions of BO investors, combined with the discipline of debt, lead to better-run firms and improved operational performance.

Studying a sample of 263 going private transactions between 1980 and 1987 (Lehn and Poulsen, 1989) find empirical evidence in support of Jensen's free-cash-flow hypothesis: undistributed cash flows are significantly related to a firm's decision to go private, and premiums paid to stockholders are significantly related to undistributed cash flows. ${ }^{4}$

2.3.2 Information and liquidity as critical determinants of public status. Mehran and Peristiani (2010) empirically examine a sample of companies that went private between 1990 and 2007 and argue that a primary reason behind the decision to de-list was a failure to

\footnotetext{
${ }^{4}$ Also see Kaplan (1991), Cotter and Peck (2001), Denis (1992, 1994), Lehn et al. (1990), Hite and Vetsuypens (1989), Gupta and Rosenthal (1991), and Muscarella and Vetsuypens (1990).
} 
attract financial visibility and investor interest. Firms with declining analyst coverage, institutional ownership, and low stock turnover were more likely to go private and opted to do so sooner. Similar results are reported by Bharath and Dittmar (2010), who study a sample of going-private transactions from 1980 to 2004. Both studies compare determinants of going private for those firms that were acquired by $\mathrm{BO}$ funds and those that were taken over by other investors (e.g., management and other private companies), and find that they go private for similar reasons. For example, non-LBO going-private transactions are more likely if the firms have less analyst coverage and higher free cash flow, as are LBO transactions. Thus, the findings in these studies explain why firms go private in general more than why firms specifically choose to go private under the buyout fund ownership. ${ }^{5}$

2.3.3 Economic rationale of private-to-private buyouts. While the largest buyout investments are often public-to-private deals (with high leverage) and they tend to receive heightened attention from media due to their size and high profile, the vast majority of buyout targets are private firms and these transactions often employ little to moderate leverage. For example, Stromberg (2007) reports that, of 21,397 buyout transactions between 1970 and 2007, public-to-private transactions account only for $6.7 \%$ of all transactions and $28 \%$ of firm values acquired. Thus, neither the high leverage nor the going private decision is a necessary ingredient of a buyout investment. To the best of our knowledge, little prior theoretical work exists that systematically analyses the economic roles played by privateto-private buyout investors or buyouts where high leverage is not a key ingredient. Indeed, in a recent empirical study of private-to-private buyout transactions, Chung (2009) argues that agency costs of free cash flows is unlikely to explain the buyouts of privately held targets, as ownership is already concentrated in these firms prior to buyouts. Moreover, these firms grow substantially after buyouts. These empirical findings by Stromberg, Chung and others suggest that more research is needed to understand the economic rationale of non-public-to-private buyout transactions.

\section{What Do Venture Capitalists and Buyout Investors Do?}

As discussed in the previous section, private equity investors are activist, hands-on investors whose goal is to maximise financial returns on behalf of their limited partners. The literature focuses on three main groups of activities: (i) pre-investment screening activities; (ii) monitoring and governance activities during the holding period; and (iii) exiting activities. Both VC- and BO-backing are associated with improved governance practice at the investee firms including more independent and hands-on boards and higher earnings quality.

\subsection{Economic activities of venture capitalists}

VC (and BO) firms serve as general partners of the funds they run. Since these funds have a finite lifetime, typically 10 -years long, firms raises new funds every 3-5 years

\footnotetext{
${ }^{5}$ But also see DeAngelo et al. (1984), Slovin et al. (1991), which examine management buyouts from the 1980s and find that targets who receive bids with an outside buyout investor experience significantly higher returns than those without. Also see Masulis and Thomas (2009).
} 
and at a given point in time mature firms are managing two or more consecutive funds. Funds that are 5 years old or younger take up more of general partners' time and efforts, as such funds are in their 'investment periods' - periods during which the GPs of the fund search and screen hundreds of prospective startups before committing capital to a select portfolio of 15-25 companies. Funds that are older than 5 years are in the growth and harvesting stage - a period during which the GPs' main work is to monitor and provide follow-on funds as necessary and conditional on achieving milestones, assist the portfolio companies in value-adding activities, and finally help prepare the companies for exit events, either via IPOs or acquisitions. For a number of companies that are not sufficiently successful to warrant profitable exits, this is also a period in which VCs get involved in restructuring or shutting down the operations.

Gorman and Sahlman (1989) report 49 responses to a questionnaire mailed (this is pre-email era!) to 100 venture capitalists in 1984 . They provide the first evidence on how VCs actually spend their days. For example, VCs (who responded) spend about half their time monitoring nine portfolio investments; of these, five are companies on whose boards they sit. As board members, a VC typically devotes 80 hours of on-site time and 30 hours of phone time per year in direct contact with each company. Fundraising, strategic analysis, and management recruitment are the most commonly mentioned activities that they perform. The number of companies VCs monitor seems to have changed little since 1984: Metrick and Yasuda (2010a) report that, for a sample of funds raised between 1993 and 2006, a mean (median) VC fund invests in 24 (20) companies and has 5 (4) partners, suggesting that a partner at a typical VC firm running two funds on average would monitor close to 10 firms at a given point in time. ${ }^{6}$

How do VCs screen startups before committing capital, and what kind of companies do they tend to fund? Kaplan et al. (2009) examine $50 \mathrm{VC}$-backed companies that eventually went public, and find that business lines remain stable from early business plan to IPO, while management is frequently replaced. Therefore, the results suggest that the business (idea) rather than the management team should be the key screening criteria for investments in startups. The evidence of frequent management turnover is in line with Hellmann (1998), which explains that in equilibrium founders voluntarily relinquish control of the firm so that VCs have incentives to search for a superior management team without fear of holdup. ${ }^{7}$

In an empirical study of a large, comprehensive small business dataset, Puri and Zarutskie (2010) find that VC-backed companies tend to be younger, faster-growing, and larger compared to non-VC-backed companies. Thus, scalability is an important criterion that VCs use to screen prospective investments' market potential, while profitability is not. The tendency for faster growth of VC-backed firms may also contribute to the higher CEO turnover rate: rare are individuals who have the talent and skill sets of founderCEOs of startups as well as those of professional managers running multi-billion dollar companies.

\footnotetext{
${ }^{6}$ For example, a hypothetical XZY Venture Partners with 4 partners may have their first fund, $\mathrm{XYZ} \mathrm{I}$, that is 7 years old and has 20 portfolio companies, and another fund XYZ II that is 4 years and nearly fully funded, with another 20 companies. $(20+20) / 4=10$.

${ }^{7}$ Hellman and Puri (2002), Baker and Gompers (2003), and Hochberg (2003) find that replacement of founder-CEOs is more likely and/or occurs faster at VC-backed companies compared with non-VC-backed firms.
} 
Do VCs fund high-growth companies, or do companies funded by VCs grow fast? According to Inderst and Mueller (2009), the answer seems to be a little bit of both. The paper shows that, in a competitive product market, new ventures financed by VCs (active investors) may prey on rivals by 'strategically overinvesting' early on, and dominate their industry peers in the long run. The value of VCs is greater in highly competitive industries as well as in industries with network effects and economies of scope, as is typical for many 'new economy' industries. ${ }^{8}$ Collectively, these papers support the view that a VC business model works the best in newly emerging markets that can support fast growth and large scale, and VCs strategically focus their efforts and attain skills that enable them to identify strong business ideas in such markets and push them to achieve high growth in a relatively short period of time for attractive financial returns.

Once VCs find and fund their portfolio companies, how do they monitor/influence them, who receive more monitoring and why, and is monitoring valuable to the companies? VC investments are often staged, and by structuring investments to be dispensed over many incremental rounds, each conditional on some measure of performance, rather than an upfront payment for the whole project, VCs exercise their rights to monitor, evaluate the interim performance and (and if found unpromising) abandon the project mid-course. Consistent with the monitoring role of staged financing, Gompers (1995) analyses a sample of 794 VC-backed companies' investment history and finds that firms with higher levels of agency costs (measured by, e.g., the ratio of intangible to total assets, the market-to-book ratio, and R\&D intensity) are monitored more frequently, i.e., durations between their investment rounds are shorter.

Venture capitalists appear to influence the way in which their portfolio companies are run, staffed, and funded. Using a dataset on Silicon Valley start-ups, Hellmann and Puri (2002) find that VC-backed companies are more professionalised, as measured by human resource policies, adoption of stock option plans, and hiring of a marketing VP. Using a sample of European VC deals, Bottazzi et al. (2008) find that venture capitalists with more prior business experience are more hands-on investors, helping with recruiting and fundraising for and interacting more frequently with their portfolio companies. ${ }^{9}$ Both Baker and Gompers (2003) and Hochberg (2003) find that VC backing is associated with more independent boards. Lerner (1995) reports that board representations increase around CEO turnover and is higher the more distant the companies and VCs are from each other. Cornelli et al. (2010), using East European VC investment data, document disciplinary roles (manager evaluation and firing) played by VC-backed company boards. Moreover, Hochberg (2003) also finds that VC-backed IPO firms exhibit lower earnings management than non-VC-backed counterparts. ${ }^{10}$

Several studies document the economic roles of VCs in innovation. Kortum and Lerner (2000), for example, find that increases in VC funding in an industry is associated with significantly higher patenting rates, while controlling for the effect of unobservable arrivals of technological opportunities that affect both $\mathrm{VC}$ activities and patenting by using instruments. Patents filed by VC-backed companies are more valuable (cited and litigated more frequently) than those filed by non-VC-backed companies. Hellmann and Puri (2000) find that VC backing is associated with a significant reduction in the time

\footnotetext{
${ }^{8}$ In line with this view of VCs' comparative advantage, Hellmann and Puri (2000) find that first-mover firms are more likely to obtain venture capital than follower (imitator) firms.

${ }^{9}$ The activities documented in these more recent papers echo those from Sahlman (1990).

${ }^{10}$ See similar evidence for BO-backed companies in Katz (2009).
} 
to bring a product to market and that this is especially true for firms with first-mover positions in the markets. Finally, Tian and Wang (2010) find evidence that firms backed by VCs with higher tolerance for failure (measured by the VCs' willingness to keep funding a startup conditional on not meeting milestones) stay innovative long after VCs exit as investors. ${ }^{11}$ Overall, the evidence is strong that VCs pour funds into innovator firms (who present the greatest 'homerun' opportunities) and push for their dominance as first movers in new markets (but see Caselli et al. (2009) for a contrary European evidence). ${ }^{12}$

Some studies focus on VCs' roles as managers of a portfolio of firms that may collaborate as well as compete with each other. Lindsey (2008) provides evidence that strategic alliances are more frequent among companies sharing a common venture capitalist, and that the effect is concentrated in alliances in which contracting problems are more pronounced (also see Gompers and Xuan (2009)). Inderst et al. (2007) argue that, by staging funding and rationing a fixed amount of capital (bound by the size of committed capital) among a portfolio of companies in later stage financing, VCs not only improve their bargaining power but also enhance entrepreneurs' incentives to outperform their peer portfolio companies.

Given these highly specialised, hands-on activities that VCs perform, it is not surprising that the most common backgrounds VC partners have are some combination of technology / science and business. According to Wieland (2009), among the 125 partners from $15 \mathrm{VC}$ firms, $60 \%$ of them hold a degree in science or engineering; particularly common is a bachelor's degree in engineering, which $44 \%$ of VCs hold. The most common postgraduate degrees held by VCs are MBA degrees - held by $62 \%$ of them. $78 \%$ of them have worked in the IT or health care sector, $37 \%$ have worked as entrepreneurs in startups, and $38 \%$ as line manager at a listed firm. ${ }^{13}$

There is some empirical evidence that capital markets perceive $\mathrm{VC}$ monitoring (as proxied by $\mathrm{VC}$ reputation) to enhance firm values. For example, examining a sample of VC-backed IPO firms between 1978 and 1987, Barry et al. (1990) find that firms backed by high reputation VCs (as measured by, e.g., VC age and the number of past IPOs) experience lower underpricing for their IPOs. Krishnan et al. (forthcoming) find that more reputable VCs stay involved longer after IPOs and contribute to better long-run performance of the firms.

Finally, VCs seem to influence timing of exit events in some cases. ${ }^{14}$ Masulis and Nahata (forthcoming) provide evidence that VCs face pressure to have liquidity events towards the end of their funds' life; thus, M\&A announcements of firms backed by VC funds near the end of fund life are associated with significantly higher acquirer returns,

\footnotetext{
${ }^{11}$ In a related paper, Gompers et al. (2005) find that public companies that were once VCbacked firms themselves spawn VC-backed entrepreneurs at a significantly higher rate than others.

${ }^{12}$ Using a sample of 37 Italian VC-backed IPO firms and matched pairs of 37 non-VC-backed IPO firms, Caselli et al. (2009) find that VCs choose more innovative firms at the time of backing, but post-transactions VC-backed firms do not pursue more innovative business plans.

${ }^{13}$ Similar findings are reported by Zarutskie (2010) for first-time VC partners. Also see Gompers et al. (2009).

${ }^{14}$ Also see Bayar and Chemmanur (forthcoming) for a theoretical analysis of IPO vs. acquisition exit decisions by entrepreneurs and VCs.
} 
suggesting these are fire sales. (Puri and Zarutskie 2010) also document time-varying survival rates of VC-backed companies: they are higher relative to non-VC-backed firms in the first four years after receiving funding, but conditional on surviving past this point, are lower in the subsequent periods.

\subsection{Economic activities of buyout investors}

In one of the early papers examining the first wave of buyouts in the 1980s, Kaplan (1991) document status changes of LBO target firms over time and find that LBOs are neither short-lived nor permanent: Median target firms spend about 7 years remaining private. Stromberg (2007), Guo et al. (2011), and Lopez de Silanes et al. (2010), using data sets that involve more recent $\mathrm{BO}$ transactions, report median holding periods of 9 , 4 , and 4 years, respectively.

What types of firms are likely to become buyout targets? Opler and Titman (1993) find that, consistent with free-cash-flow theory, LBO target firms have both low Tobin's $q$ and high cash flows relative to non-target firms, and are more diversified. Firms with large expected costs of financial distress (measured as those with high R\&D expenditures) are less likely to do LBOs. ${ }^{15}$

With respect to post-investment monitoring activities of buyout investors, Cotter and Peck (2001) find that buyout specialists use more long-term debt and are more active monitors of firms and their monitoring roles substitute for tighter debt terms in motivating managers to run their firms efficiently. In a case study, Baker and Wruck (1989) examine the LBO of O.M. Scott \& Sons and document that the adoption of a strong incentive compensation plan, a reorganisation and decentralisation of decision making, and the relationships between managers, PE sponsors, and the board of directors were as important as the disciplining power of heavy debt load and management equity ownership in improving performance of the firm. ${ }^{16}$

More recently, Kaplan et al. (forthcoming) examine the relationship between CEO characteristics and subsequent performance of $\mathrm{BO}$ portfolio companies and find that resoluteness and execution skills, but not communication and interpersonal skills, translate to good performance. Acharya et al. (2009) study a hand-collected sample of boards of UK, BO-backed companies and find that they play a markedly active role 'leading' the company strategy and operations whereas boards of non-BO backed, plc companies play a more remote, supervisory and monitoring role. Cornelli and Karakas (2008) study UK firms that went through public-to-private transactions and find (1) significant reduction in board size, (2) replacement of outside directors with BO firm employees, (3) greater BO firm presence at boards of companies that require more time and efforts (e.g., firms that experience CEO change at the time of transactions), and overall high turnover both of directors and CEOs during investment periods ${ }^{17}$ Focusing

\footnotetext{
${ }^{15}$ Also see Lehn and Poulsen (1989), Lehn et al. (1990), and DeAngelo and DeAngelo (1987).

${ }^{16}$ Also see Denis (1994) for an in-depth case study comparison of an LBO vs. a leveraged recapitalisation.

${ }^{17}$ Consistent with a tighter leash with which BO-backed company executives are managed, (Edgerton 2010) finds that LBO target firms significantly reduce the size of their corporate jet fleets compared with those of comparable public firms. Brown et al. (2009) find that LBO target firms bargain harder with suppliers post transactions. The effect is absent in cases of
} 
on a sample of public-debt issuing private firms that later have IPOs, Katz (2009) finds that BO-backed firms have higher earnings quality than those that do not have BOsponsorship, engage less in earnings management, and report more conservatively both before and after the IPO. These findings are consistent with tighter monitoring and reputational considerations exhibited by $\mathrm{BO}$ investors.

One particularly controversial issue is how buyout investors affect employment, productivity, and investment activities at the portfolio companies. ${ }^{18}$ Davis et al. (2008) find that US buyout target firms reduce more pre-existing jobs relative to controls both before and after the transactions, but create more jobs at new establishments they open after transactions. Higher old-job destructions of buyout target firms are driven by service sector firms rather than manufacturing firms. Harris et al. (2005) find that UK buyout target plants are less productive pre-transaction and experience a substantial increase in productivity after a buyout, due to reduction in labour intensity of production via outsourcing of intermediate goods and materials. Bernstein et al. (2010) analyse the impact of buyouts on industry performance across nations (the USA, the UK and continental Europe) and find that high BO activity is associated with faster growth in productivity and employment. Lerner et al. (2011) find that LBOs do not decrease patenting activity of target firms, patents applied for by target firms are more cited, and are more concentrated in the most important and prominent areas of companies' innovative portfolios. Overall, evidence suggests that buyout target firms become strategically more focused, which leads to existing job loss where inefficiency existed, and at the same time results in focused expansions and job creations in areas of their core strengths.

\section{Performance: Risk-adjusted Returns, Persistence, and Sources of Performance}

Both $\mathrm{VC}$ and $\mathrm{BO}$ funds make illiquid investments in private companies and fund returns are reported either as IRRs or value multiples, not time-weighted returns. At the deal level, investment return realisations are low frequency events, and may not be observed for deals that stagnate and are never cashed out. These features of PE investments make it challenging to analyse their performance using standard risk-adjustment methods.

$\mathrm{VC}$ and $\mathrm{BO}$ asset classes also share similarities in the reported findings about their performances. While neither asset class appears to significantly outperform public benchmarks after risk adjustments, there seems to be some performance persistence among firms. These findings contrast sharply with findings in the mutual fund literature. The persistence is stronger in $\mathrm{VC}$ than in $\mathrm{BO}$, and some explanations have been offered for the difference.

\subsection{Evidence on returns}

Data on investment performance of VC and BO investments can be gathered either at the portfolio company level, or at the fund level. While the fund-level data have the advantage of being net of fund fees and carry, aggregation at the fund level also implies loss of

leveraged recapitalisations; thus, it is the change in organisational form rather than leverage that leads to price concessions from suppliers.

${ }^{18}$ Also see Lichtenberg and Siegel (1990) and Long and Ravenscraft (1993) for earlier evidence. 
information about the timing of individual investments and exits. Loss of information is particularly problematic for cases of investment write-offs, as researchers do not observe when the funds and their investors incur actual losses. In contrast, deal-level data allow researchers to more explicitly control for selection bias arising from lack of observations for final outcomes of unsuccessful investments. However, the deal-level data may suffer from incompleteness, as documented by Kaplan et al. (2002) and Maats et al. (2010). Furthermore, studies using deal-level data are often restricted (due to data limitations) to firms that underwent IPOs and/or (in case of buyouts) firms that were publicly traded prior to transactions, which are a small and select subset of all PE target firms. The best studies in this area have either made use of a novel dataset, developed a model that helps overcome the data problem, or both.

We first review the papers studying cash flows data in and out of $\mathrm{VC}$ and $\mathrm{BO}$ funds, and then review the evidence based on company-level data. Finally, we review evidence based on VC and BO index returns, which have been developed based on both fund-level and deal-level data.

4.1.1 Fund-level performance. Cash flow data for fund partnerships are typically reported quarterly, and funds aggregate and net out any opposing cash flows that occur during a given measurement period. For example, a fund that receives a quarterly management fees of $\$ 5 \mathrm{M}$ and a capital call of $\$ 10 \mathrm{M}$, and books an exit distribution to LP of $\$ 40 \mathrm{M}$ will have a net cash outflow of $-\$ 25 \mathrm{M}$ to the investors that period, and conversely the investors (limited partners) experience a net cash inflow of $+\$ 25 \mathrm{M}{ }^{19}$ Since this observed net cash flow is already net of fees and carry, fund-level performance measures represent net returns.

Researchers face two primary challenges when using fund-level cash flows data to assess risk and returns in private equity. First, this type of data is confidential and is not easily accessible for research use. Recently, a small number of researchers have overcome this obstacle and gained access to data, either from a single large investor or from vendors such as Venture Economics or Preqin. Second, because investments are illiquid and individual project returns are not fully realised until after the end of the fund life, usually ten years, it is not easy to measure risk ('beta') at the fund level using standard time-series correlations with the market and other factor returns. Existing studies' approach to address this data limitation varies, though all employ some version of market-return adjustment with an effective assumption of beta $=1 .{ }^{20}$

Existing studies offer somewhat mixed conclusions about the fund-level performance of private equity relative to public equity markets. Using a large fund-level cash flow dataset of private equity funds provided by Venture Economics, Kaplan and Schoar (2005) find that net-of-fee returns of private equity funds (both venture capital and buyout) approximately equal the S\&P 500, in the sense that discounting fund inflows and outflows using the same-period S\&P 500 returns and dividing the sum of discounted present values of outflows by the sum of discounted present values of inflows yields a

\footnotetext{
${ }^{19}$ In this example, there may or may not be a carry payment to the fund manager (general partners); but this amount (if any) is already netted out of the total exit distributions and is reflected in the exit distribution to LPs.

${ }^{20}$ Beta estimates obtained using deal-level data or index returns (reported in Sections 4.1.2 and 4.1.4) suggest that this assumption is too low for $\mathrm{VC}$, whereas it may be reasonable for BO.
} 
ratio of approximately one ('public market equivalent', or PME). The inference is made by focusing on 746 funds which are mostly funds started before 1995 (and thus are fully liquidated).

In contrast, Ljungqvist and Richardson (2003) find that the average net-of-fee IRR of their sample funds is $19.8 \%, 5.7 \%$ higher than the IRR of a simulated investment in the S\&P 500 index under an identical time schedule of cash outflows (14.1\%). They assign industry-adjusted risk measures to individual portfolio companies and find that the excess performance results are robust to this further refinement on risk-adjustments. ${ }^{21}$ Ljungqvist and Richardson obtain data from a single large investor (LP); thus their sample is somewhat smaller - the core sample is 73 funds raised between 1981 and 1993 - and skews toward large, buyout funds and away from venture capital funds. Their sample also outperforms the Venture Economics population of funds in eight out of eleven vintage years. Thus their results may be more representative of buyout fund performance than venture capital fund performance.

Jones and Rhodes-Kropf (2003) differ from other studies reviewed here in that they use GP estimates of value changes rather than realised returns to estimate quarterly private equity returns. Using the Venture Economics data, they find the beta of 1.80 and the annualised alpha of $4.68 \%$ for $\mathrm{VC}$ funds, and the beta of 0.66 and the alpha of $0.72 \%$ per annum for BO funds.

Phalippou and Gottschalg (2009) start with a dataset similar to that used by Kaplan and Schoar, but make several adjustments to the measurement of the $\mathrm{PME}^{22}$ and conclude that the performance reported by previous research is overstated. They argue, in particular, that (i) the funds included in Venture Economics perform better than those funds excluded from Venture Economics but whose deal-based performance is available from VentureXpert, a database of portfolio company-level investments; (ii) Net-Asset-Value of unrealised investments tend to be inflated and should be written-off when calculating fund distributions in the last period of the fund's life; and (iii) it is more conservative to use present values of fund inflows as weights rather than the size of committed capital, because poorly-performing funds tend to invest faster, and thus have larger present values of cost basis (inflows) than better-performing funds, which tend to invest more slowly, do. After implementing these three adjustments, they show that the PME of their broadened sample is reduced from 1.01 to 0.88 .

Finally, Driessen et al. (2009) develop and apply a GMM-style methodology to a fundlevel cash flows dataset consisting of 958 mature private equity funds. Their estimation methodology is based on a moment condition that equates the expected discounted value of the cost basis of an investment in a portfolio company to the expected discounted value of the exit value of the investment; in implementation, because the deal-level cash flow

\footnotetext{
${ }^{21}$ The refinement implicitly assumes that BO portfolio companies have similar leverage to their industry peers, which have levered equity beta of around 1. On the one hand, to the extent that BO portfolio companies are more highly levered, this may account for some of the reported excess performance here. Axelson et al. (2010) show that LBO firms' leverage levels are not explained well by those of their public-market industry peers. On the other hand, BO beta estimates using index returns and reported in Section 4.1.4 are about 1. Also see Kaplan and Stein (1990).

${ }^{22}$ Phalippou and Gottschalg (2009) use the term Profitability Index (PI) to refer to this measure; however, because Ljungqvist and Richardson (2003) use the term PI to refer to a slightly different performance measure, for consistency we refer to it as PME, as defined in Kaplan and Schoar (2005).
} 
data is not available, the method is applied to the fund-level cash flows data. Driessen et al. find a market beta of 3.21 and significant underperformance for $\mathrm{VC}$ funds, and a low beta $(0.33)$ and mixed evidence on performance for $\mathrm{BO}$ funds. While the $\mathrm{VC}$ result is similar in magnitude to Korteweg and Sorensen (2010), the BO result is at odds with studies using index returns (reported in Section 4.1.4).

4.1.2 Deal-level performance: Venture Capital. Brav and Gompers (1997) compare the longrun performance of VC-backed IPOs and nonventure-backed IPOs completed between 1972 and 1992 and find that VC-backed IPOs generally perform better than nonventurebacked IPOs. They identify the smallest nonventure-backed IPOs as the main drivers of long-run underperformance of IPO firms - these firms significantly underperform benchmarks in the Fama-French 3-factor model. In contrast, VC-backed IPOs do not underperform.

Two papers develop econometric methods that measure risk and return of VC investments at the deal level while correcting for sample selection. ${ }^{23}$ Cochrane (2005) measures the mean, standard deviation, alpha, and beta of VC investments, using a maximum likelihood estimate that corrects for selection bias. The selection-corrected mean arithmetic return is $59 \%$, with the mean arithmetic alpha of $32 \%$. Volatility is $89 \%$. While high, these figures are generally comparable to those of the smallest NASDAQ stocks in the estimation period. Korteweg and Sorensen (2010) develop a model that corrects for the higher frequency of observations for better performing investments and obtain beta estimates of VC investments in the range of two to three, much higher than previously reported in the literature. Similarly, VC betas close to two are obtained when regressing $\mathrm{VC}$ index returns on contemporaneous and lagged market returns and summing over the coefficients, as discussed in Section 4.1.4.

4.1.3 Deal-level performance: Buyouts. Andrade and Kaplan (1998) find that buyout transactions in the 1980s created value despite high leverage and subsequent financial distress (also see Kaplan (1989a, b). Guo et al. (2011), in a study examining buyout transactions completed between 1990 and 2006, find that they earned high financial returns on average and had operating performance comparable to or slightly succeeding benchmark firms. Tax benefits of leverage, multiple expansion (market timing), and operating gains equally contributed to the results.

Holthausen and Larcker (1996), in an early study of the first wave of buyouts focused on reversed LBOs, find that these firms' operating performance is significantly better than their industry peers for the first four years after the IPO events, while there is no evidence of abnormal common stock performance. They, however, also document some evidence of a decline in performance over time. Similar improvements in operating performance are also reported in Muscarella and Vetsuypens (1990). Degeorge and Zeckhauser (1993) argue that reverse LBOs' operating performances peak around the time of their IPOs, due to market timing by insiders. They further find that their post-IPO stock performance is normal relative to peers, suggesting that the market appropriately discounts this effect. Echoing these earlier findings, Cao and Lerner (2009) examine post-IPO long-run performance of reversed LBOs completed between 1981 and 2003 and find that they perform as well as or better than other IPOs and the stock market as

${ }^{23}$ Also see Gompers and Lerner (1997). 
a whole. Like Holthausen and Lacker, they also find that performance deteriorates over time.

Kracaw and Zenner (1996) study the announcement effects of buyouts on the stock prices of targets and lending banks and find positive wealth effects for lending banks and targets. Interestingly, they find negative wealth effects on the stock prices of targets of leveraged recapitalisations. ${ }^{24}$ DeAngelo et al. (1984) also find that public shareholders gain about $22 \%$ in public-to-private buyouts.

Lopez de Silanes et al. (2010) study a large sample of buyout transactions and their deal-level returns. They find that $10 \%$ of deals result in bankruptcy while $25 \%$ of them have an IRR over $50 \%$. They also find a negative relationship between deal-level returns (IRRs) and the size of the funds investing in them: the median IRR of investments held by the top decile BO firms is $16 \%$ while investments held by the bottom decile firms have a $36 \%$ median IRR. The authors argue that diseconomies of scale are significant in the BO industry. Groh and Gottschalg (2009), using a data set of 133 US buyouts, construct a mimicking levered public equity portfolio for each deal (using deal-specific debt-to-equity ratios) and show that many such mimicking portfolios default during the holding period. Their results highlight the difficulty of proper benchmarking for BO returns.

4.1.4 Asset-class-level returns. Several vendors have developed VC and BO indices by aggregating either fund-level or deal-level data. ${ }^{25}$ This enables researchers to estimate risk-adjusted performance of $\mathrm{VC}$ or $\mathrm{BO}$ as an asset class using standard factor models. However, returns thus constructed still suffer from a stale price problem: company valuations are updated infrequently and only when companies either receive new rounds of financing (in cases of VC) or have exits. Not addressing stale price issues leads to underestimated beta and over-estimated alpha. Woodward (2009), Metrick and Yasuda (2010b), and Barber and Yasuda (2010) address this problem by including lagged values of factor returns in the regressions and sum over the estimated coefficients across lags. ${ }^{26}$ Consistent with stale prices, lagged factor returns (especially market returns) are often significant explanatory variables. Market betas estimated this way are approximately 1 for $\mathrm{BO}$ and 2 for $\mathrm{VC}$, and alphas are not significantly different from zero for either asset class.

4.1.5 Summary. The evidence on whether VC and BO funds achieve excess performance is mixed. This is due to several reasons. First, many of the studies that employ fund-level cash flow data make an effective assumption that market beta for the asset class is 1 , which may or may not be appropriate. Studies using deal-level data or index returns and explicitly estimating market beta while correcting for other data issues (e.g., sample selection, stale prices) tend to obtain beta estimates closer to 2 for $\mathrm{VC}$, and around 1 for BO; more data and more studies with innovative methodology can further improve the precision of these estimates. Second, some studies use self-reported portfolio values as

\footnotetext{
${ }^{24}$ In contrast, Gupta and Rosenthal (1991) study leverage recaps and find positive abnormal returns to shareholders.

${ }^{25}$ Cambridge Associates publishes CA VC and PE index that are based on fund cash flow data. Dow Jones publishes DowJones Index of Venture Capital (formerly Sand Hill Index) that is based on deal-level data.

${ }^{26}$ Asness et al. (2001). 
updated by GPs to gauge performance, which may be subject to stale price problems. When these self-reported values are marked to market, as done in Gompers and Lerner (1997), it has a large positive effect on risk measures such as beta. Similarly, when lagged market returns are included, estimated betas are far larger than when they are not included. Third, in case of BO, it is difficult to adjust for the leverage risk that may vary from deal to deal and from fund to fund. Even if the average BO beta exposure is close to 1, it may not be uniform across funds, and cross-sectional performance variation may or may not be coming from differences in the levels of systematic risk (via leverage or otherwise) taken by individual funds. These and other known data issues (such as stale prices, illiquidity premium, selection bias, and missing data on defunct dates) likely account for the mixed results thus far in the literature. Solving methodological challenges and/or overcoming data limitations, and reconciling existing findings towards a more unified understanding of private equity performance is an important remaining research agenda in this strand of the literature.

\subsection{Performance persistence and sources of performance}

One distinguishing feature of private equity as an asset class is the evidence on performance persistence not only at the GP level but also at the LP and the entrepreneur level (in case of VC). Kaplan and Schoar (2005) document that GPs whose funds outperform the industry in one fund are likely to outperform the industry in the next and vice versa. The persistence is found not only between two consecutive funds but also between the current fund and the second previous fund. Persistence is found in both $\mathrm{VC}$ and $\mathrm{BO}$, but is stronger in VC. Metrick and Yasuda (2010a) provide an explanation and supporting empirical evidence as to why persistence is weaker in BO: when $\mathrm{BO}$ fund managers gain experience, they increase the size of their funds much faster than VC fund managers do, thereby increasing the per-partner capital under management. In line with this explanation, Marquez et al. (2010) argue that PE fund managers (and VC fund managers more than $\mathrm{BO}$ fund managers) with positive alpha allow their superior performance to persist because there is assortative matching between funds and portfolio companies along this dimension. Because PE fund managers haver incentives to signal positive alpha to potential investees in order to be matched with the best firms, they are willing to not fully capture the surplus from their alphas by either increasing the fund size or their fees. Hochberg et al. (2010b), on the other hand, argue that persistence results from the hold-up power of incumbent fund investors (limited partners).

In a different vein, Lerner et al. (2007) examine the returns that institutional investors realize from private equity and find that endowments (and to a lesser degree public pensions) outperform other types of investors by a large margin. Part of the outperformance appears to be due to their better ability to select superior funds. Finally, (Gompers et al. 2010) study serial entrepreneurs and find that entrepreneurs who were successful in prior ventures are much more likely to succeed than others (also see Gompers et al. 2009). One interpretation is that others perceive them to have skill and are more willing to commit resources. Thus, success begets success and strengthens performance persistence.

These results are markedly different from those in other asset classes such as mutual funds, and are thus striking. How the persistence results found at the GP level and at the LP level relate to one another is another interesting open question. At the first glance, it appears that high-performing PE (and especially VC) firms are matched with 
sophisticated investors (endowments and public pension funds). However, Phalippou (2010) argues that the performance persistence of VC funds as reported in Kaplan and Schoar (2005) is mainly driven by unsophisticated investors; VC funds that are expected to be backed by skilled investors do not exhibit performance persistence and a significant flow-performance relationship. This finding is at odds with the simple matching story. Richer evidence that sheds more light on the persistence phenomenon is warranted.

Below, we review the extant literature that examines both sources of performance and possible explanations for performance persistence for $\mathrm{VC}$ and $\mathrm{BO}$. We first review the studies that focus on $\mathrm{VC}$ and then on $\mathrm{BO}$.

Studies on the determinants of VC performance fall into two broad categories: those that examine how VC-company matching at times of investment leads to differentials in performance, and those that examine how VC's post-investment activities (including exit decisions) are related to investment performance.

Several studies document that established VCs exercise pricing power, which offers an explanation for the performance persistence phenomenon and seems particularly valuable in hot markets. Using a unique hand-collected sample of first-round recipient companies that received offers from multiple VCs, Hsu (2004) finds that high-reputation VCs' offers are three times more likely to be accepted, and moreover that they acquire startup equity at a $10-14 \%$ discount. Reputation is measured as the number of past deals made in the startup's industrial segment. The finding suggests that start-ups perceive affiliation with high-reputation VCs to have positive effects on their firms' performance, and are willing to share the rent with such VCs. The effect itself can be either certification, value-added, or both.

Gompers and Lerner (2000) find that competition for a limited number of attractive investments leads to a positive relationship between capital inflows and valuations of new investments. ${ }^{27}$ While they find that changes in valuations are not related to the ultimate success of the firms, Kaplan and Schoar (2005) find that market entry (the number of new funds entering the market, and thus similar to capital inflows) and fund performance are countercyclical (see also similar results in the context of European VC and BO investments in Diller and Kaserer (2009)). To the extent that higher valuations affect the division of exit values in entrepreneurs' favour, but not the exit values, the two findings are reconcilable. Significantly, Kaplan and Schoar also find that the performance of funds raised by high-reputation VC firms (firms with more previous funds) is less sensitive to market entry. Combined, findings of these three studies suggest that reputable VCs avoid the negative effects of capital inflows on performance by successfully insisting on favourable investment terms even in hot markets. Consistent with this interpretation, Gompers et al. (2008) find that VC firms with the most industry experience increase their investments the most when public market signals become more favourable. Their investments are more responsive than firms with less industry experience, and the increased investment rate does not adversely affect subsequent success rates.

How do reputable VC firms sustain their pricing advantage? Several studies argue that the network among VCs who engage in repeated transactions with each other through deal syndication serves as a source of performance as well as barriers to entry. Hochberg et al. (2007) find that funds run by better-networked VC firms perform significantly better (measured as better successful exit rates). While a better network status can either

\footnotetext{
${ }^{27}$ Also see Gompers (1994) and Gompers and Lerner (1998b) for analysis of determinants of capital flows.
} 
be a source of better screening or conversely a result of better value-adding skills, Hochberg et al. (2010a) further argue that VCs use networks as barriers to entry, and benefit by getting low prices for deals. Hochberg et al. (2010a) also find that more densely networked markets experience less entry, and document strategic behaviour by both entrants (who try to enter by syndicating with incumbents) and incumbents (who freeze out other incumbents that facilitate entry by newcomers).

While a number of studies document how VCs' monitoring activities affect VCbacked firms' operational characteristics (e.g., board composition, earnings quality, and personnel policy), as discussed in Section 3, few studies actually document a relationship between VCs' post-investment activities and investment performance. ${ }^{28}$ One exception is Bottazzi et al. (2008) which, using a sample of European VC deals, find that companies that receive funding from more activist VCs are more successful. In another study, Lindsey (2008) documents facilitation of strategic alliances among portfolio companies as a new value-added role of venture capitalists, and finds these alliances improve the probability of exit for VC-backed firms.

Besides monitoring and other interim activities, post-investment $\mathrm{VC}$ activities also include executing exits and distributing exit proceeds back to investors, and the literature offers some evidence of market-timing skill as a source of performance for VCs. Using a sample of VC-backed biotech firms between 1978 and 1992, Lerner (1994b) finds that companies go public when equity valuations are high, and that seasoned venture capitalists (a common measure of VC reputation in the literature) are particularly good at taking companies near market peaks. VC returns on investments are realised (and used to calculate fund returns and carry) not when the firms go public, but when the VCs decide to distribute the now-public stocks to their investors. ${ }^{29}$ Thus, VCs' abilities to time the public stock market could contribute to their fund returns. Gompers and Lerner (1998a) examine a sample of in-kind distributions by VCs to their limited partners and find evidence that VCs use inside information to time stock distributions after substantial price run-ups.

While a positive relationship between $\mathrm{VC}$ reputation measures and investment performance is extensively documented, this could be due to either reputable VCs matching with higher ex-ante quality firms (because of better screening ability, better proprietary deal flow, better network, or all of the above), or reputable VCs possessing better monitoring skills. Disentangling the two effects is an important yet challenging research goal. A standard econometric approach with instruments that affects VC reputation measure (e.g., experience) but does not affect investment outcome is difficult to find in the VC setting. For example, geography-based instruments are valid in other contexts, but in VC investments, proximity affects effectiveness of monitoring and value-added activities, and thus cannot be excluded from the second-stage equation. ${ }^{30}$

\footnotetext{
${ }^{28}$ One perennial problem is the difficulty of separating out the effects of sorting from the effects of value-added activities. See the discussion of Sorensen (2007) below.

${ }^{29}$ Although it is also possible for the VCs to sell the fund's stock holdings in the open market and distribute the cash proceeds to investors, it is more common practice for them to make in-kind distributions in cases of IPO exits. One reason is that as insiders of the firms, VCs' sales of stocks are more restricted than sales by limited partners. Another is that some limited partners may prefer to receive in-kind distributions, thereby controlling the timing of liquidations.

${ }^{30}$ See Chen et al. (2010) for geography of venture capital.
} 
Prior to this realization, several papers made valiant but incomplete efforts to solve these problems. Sorensen (2007) explicitly tackles this problem by using the identifying assumption that VCs and firms' participation in a particular market, where the market is defined by a region-year pair, is exogenous and is independent of error terms in the model. Then, presence of other agents affects investment decisions and leads investors with differing experiences (reputation) to invest in companies with similar unobserved quality for exogenous reasons. Sorensen finds that the companies funded by more experienced VCs are more likely to go public (a success measure), and that sorting is almost twice as important as value-added in explaining the difference in IPO rates.

Finally, Nahata (2008) proposes a new measure of VC reputation and shows it predicts performances of portfolio companies better than alternative measures. His proposed measure is IPO capitalization share and is based on cumulative market capitalization of IPOs backed by the VC. Nahata argues that this measure captures both VC screening and monitoring expertise.

Existing studies examining determinants of $\mathrm{BO}$ performance have tended to focus on two factors: whether BO reputation (or stronger relationships with banks) has positive effects on the fund performance via better debt pricing, and whether competition (or lack thereof) among bidders at the time of investments drives up (down) purchase prices.

Using a sample of 180 public-to-private LBOs, Demiroglu and James (2010) find that reputable $\mathrm{BO}$ firms are better at market timing in credit markets (increasing deal activities more when credit spreads are low and lending standards are lax), and that they get better loan terms (lower spreads, longer maturities, higher portions of institutional loans). Though buyouts sponsored by reputable BO firms are more levered, the valuations they pay are not higher. While Demiroglu and James do not provide a direct evidence on fund performance, the findings suggest that reputable BO firms' better pricing power vis-àvis lenders is a source of performance persistence in buyouts. Their findings on market timing and pricing power echo parallel findings on VC in Hsu (2004) and Gompers et al. (2008). ${ }^{31}$ Ivashina and Kovner (2010) document that BO firms with stronger bank relationships obtain better spreads and covenant terms. The results in Demiroglu and James and Ivashina and Kovner appear to be related, as there is likely to be a positive correlation between $\mathrm{BO}$ reputation and the strength of their relationships with lenders.

Kaplan and Stein (1993) examine pricing and financial structure of large MBOs in the 1980 's and find that over time the deals were struck with higher ratios of prices to cash flows, employing higher ratios of debt obligations to cash flows and more junk bonds as opposed to private debt, and more upfront monetary rewards for management teams and dealmakers. Later-period buyouts were more likely to experience defaults and costly financial distress, and Kaplan and Stein argue that overheating in the buyout market, driven by the demand for junk bonds, is the most likely explanation. ${ }^{32}$

Several recent studies examine determinants of the degree of competition among bidders and their effects on buyout performance in more recent buyout booms. These studies tend to focus on large, public-to-private transactions where it is common for the seller to receive multiple offers and banks are hired to assist in the bidding process. In a theory paper, Povel and Singh (2010) analyse a recent phenomenon called 'stapled finance', whereby a seller arranges a pre-packaged loan commitment for whoever

\footnotetext{
${ }^{31}$ Note, however, that in case of VC the rent is extracted from entrepreneurs, whereas in case of $\mathrm{BO}$ the rent is extracted from lenders.

${ }^{32}$ Also see Gompers (1998) for related evidence for VC in the late 1990's.
} 
wins the bidding contest, and show that stapled finance increases bidding competition and benefits the seller by increasing valuations, even though the seller would need to compensate the arranging bank for offering the loan. The results suggest that buyers of stapled finance transactions perform worse than non-stapled finance transactions, ceteris paribus. Consistent with the theoretical prediction of Povel and Singh, Boone and Mulherin (2009) find that staple financing is associated with increased competition, i.e., a greater number of firms making non-binding and binding private offers for the target firm.

Another aspect of the bidding process that received attention during the recent buyout boom is the so-called club deals or consortiums where multiple BO funds join forces to purchase a target firm as a consortium. ${ }^{33}$ The evidence is mixed on the competitive effect of club deals. Examining a sample of US public-to-private buyouts conducted by prominent BO firms, Officer et al. (2010) find that club deals are associated with lower premiums paid to target shareholders compared to solo-sponsored deals, especially among deals before 2006 and in target firms with low institutional ownership. Officer et al. argue that the most likely explanation is that club deals dampen competition and facilitate collusion. In contrast, analysing a sample of 870 takeovers of publicly traded targets, Boone and Mulherin (2009) find that, while target abnormal returns are somewhat lower in consortium deals in the short run, the results do not hold for longer event windows. Boone and Mulherin also find that BO takeovers (both solo and consortium deals) are generally associated with greater degrees of competition than other types of bidders. They thus reject the view that $\mathrm{BO}$ consortium deals facilitate collusion, which is at odds with Officer et al.'s conclusion. Marquez and Singh (2010) present a theoretical model that shows that whether club deals hurt (via lower premiums paid) or benefit (via bundled value-adding expertise of multiple PE firms) target shareholders depend on both the number of potential bidders and bidding costs, thus suggesting that the extant empirical findings may be reconcilable.

\section{Contracts}

Contracts employed by $\mathrm{VC}$ and $\mathrm{BO}$ fund managers share many features. At the fund level, limited partnership agreements signed between GPs and LPs are structured quite similarly. Both $\mathrm{VC}$ and $\mathrm{BO}$ funds are closed-end, finite-life (typically 10 years) partnerships where GPs earn management fees annually as a pre-determined percentage of base capital (e.g., committed capital), and carried interest, which entitles GPs to (typically) $20 \%$ of the fund profit. Both types of funds restrict GPs' activities (e.g., investments outside of funds, investments across funds, investment in asset classes other than private equity) through negative covenants.

At the deal level, VC contracts and BO contracts appear to be more distinct from each other. Specifically, while VC investments are minority stakes, typically made using convertible securities, and are syndicated and staged over multiple rounds, $\mathrm{BO}$ investments are one-time acquisitions of controlling stakes and are typically financed using equity and debt. Note, however, the observation made by Sahlman (1990) that

\footnotetext{
${ }^{33}$ Other papers that examine potential conflicts of interests at BO firms include Acharya and Johnson (forthcoming) and Fang et al. (2010). See Gompers and Lerner (1999b), Li and Masulis (2004), Hamao et al. (2000), and Hellmann et al. (2008) for related evidence on combining $\mathrm{VC}$ with investment banking and commercial banking.
} 
' $[\mathrm{t}]$ he debt used in LBOs is similar in function to the staged-capital-commitment process used in venture-capital deals; in neither is there much discretionary cash flow' (p. 516). Thus, both types of deal structures are aimed at disciplining the portfolio company management by taking away excess cash flows from them. Both deal-level contracts also include features like board seats that facilitate monitoring and advising roles played by GPs.

\subsection{Contracts between fund managers and investors}

Compared to the extensive literature on the contracts between VCs and their portfolio companies, the literature on the contracts between fund managers and their investors is relatively small. The earlier studies tend to focus on VCs, while the more recent papers are more likely to contain analyses of the buyout segment of the industry. Sahlman (1990) was the first analysis of contracts between VC fund managers (GPs) and investors (LPs) (also see Gompers and Lerner (1996)). Typical structures of limited partnerships are described, summary statistics of a sample of $76 \mathrm{VC}$ funds raised in 1986-87 are reported, and agency problems between GPs and LPs and contractual provisions in fund partnership agreements as potential remedies are discussed.

As discussed in Section 3, funds have a finite lifetime and VC and BO firms raise new funds every 3-5 years. Several papers examine the strategic choices made by GPs of new vs. follow-on funds. Gompers (1996) finds evidence that young VC firms take portfolio companies public earlier than older $\mathrm{VC}$ firms in order to establish a reputation and successfully raise capital for new funds. IPOs are timed to precede or coincide with raising money for follow-on funds. Similarly, Ljungqvist et al. (2007) find that younger funds invest in riskier buyouts in an effort to establish a track record, whereas established funds act more strategically in response to market conditions.

Gompers and Lerner (1999a) find that the pay of new VC funds is less sensitive to performance and varies less than that of older funds, which is consistent with a learning model rather than a signalling model. Chung et al. (2010) present a learning-based framework for estimating total pay for performance, where pay for performance arises from both explicit pay earned via carried interest in the current fund and implicit pay from expected future fundraising. They find that implicit pay from future fundraising is stronger for BO funds (which are more scalable than VC funds) and for younger funds (for which current performance is more informative about ability). Focusing on the lemons problem that arises when existing LPs face liquidity shocks and GPs need to raise funds from new investor, Lerner and Schoar (2004) find that fund managers impose more transfer restrictions when raising new funds and also funds focused on industries with longer investment cycles.

Axelson et al. (2009) analyze the optimal financing structure of buyout funds that minimizes the agency conflicts between GPs and LPs and find that a mix of ex ante and ex post financing achieves the second best. ${ }^{34}$ While the closed-end fund structure with carry compensation acts as an incentive to GPs to avoid overinvestment in good times, the deal-by-deal debt financing prevents them from making bad deals in bad times (when credit market conditions tighten). The model explains pro-cyclicality of investment volumes and counter-cyclicality of performance in the buyout industry.

\footnotetext{
${ }^{34}$ Also see Campello and Da Matta (2010) for analysis of VC funds.
} 
Using detailed records on 238 funds raised between 1993 and 2006, Metrick and Yasuda (2010a) analyze and compare the features of venture capital and buyout fund contracts. The paper builds a model of expected GP revenue as a function of their contracts with LPs, modelling carry as an option-like position on the fund assets and incorporating as model parameters fees, carry, transaction and monitoring fees (in case of buyouts), as well as leverage, portfolio concentration, and investment risk. ${ }^{35}$ About twothirds of expected revenue comes from fixed revenue components and is not sensitive to performance. BO fund managers with prior experience increase the size of their follow-on funds significantly faster than $\mathrm{VC}$ fund managers do, and as a result $\mathrm{BO}$ fund managers' per personnel revenue is higher than that of $\mathrm{VC}$ fund counterparts. The results are consistent with greater scalability of BO business.

While the partnership agreements share a number of similarities between VCs and BOs, including the fees and carry structures, there is one distinction between the two segments of private equity: the buyout funds charge various fees, such as transaction fees and monitoring fees, directly to portfolio companies, whereas VC funds do not. To the best of our knowledge no theory paper has explicitly examined implications of this practice in an agency model setting. Metrick and Yasuda (2010a) conduct sensitivity analysis and show that, ceteris paribus, these fees make total GP compensation less sensitive to performance and become disproportionately large (relative to management fees and carry) when individual buyout transactions are financed with high debt-toequity ratio (because these fees are charged on enterprise values rather than on equity values). In a paper surveying the literature findings on performance and fee structures, Phalippou (2009) argues that, among the various components of buyout fund managers' fee arrangements with investors, transaction and monitoring fees are especially opaque.

\subsection{Contracts between venture capitalists and portfolio companies}

There is an extensive literature, both theoretical and empirical, that examines the features of contracts between venture capitalists and portfolio companies. ${ }^{36}$ In part, the greater interest in VC-company contracts relative to those in BO-company contracts stems from the fact that the relationships between VCs and entrepreneurs resemble the theoretically pristine (but hard to find in practice) setup of principal-agent models that are used in much of the contract-theory literature (Kaplan and Stromberg 2001). Thus, the VC setup offers a rare natural laboratory to test the implications of the theory of the firm without the usual confounding factors, e.g., the dispersed stock ownership and shortterm pressures associated with publicly traded firms. That said, we note the dearth of papers on contracts used in buyout transactions and expect it to be a growth area in the literature.

\footnotetext{
${ }^{35}$ Also see Choi et al. (2011) that extends the model in Metrick and Yasuda (2010a) and examines the effects of fund terms on fund managers' incentives.

${ }^{36}$ For definitions and detailed explanations of features included in standard VC contracts, see, e.g., Sahlman (1990), Metrick and Yasuda (2010b, Chapters 8 and 9), as well as the model term sheet on NVCA's website, http://www.nvca.org/index.php?option=com_content\&view $=$ article $\&$ id $=108 \&$ Itemid $=136$. For prevalence of various contract features in real-world contracts, see, e.g., Sahlman (1990), Kaplan and Stromberg (2003, 2004), and Dow Jones Venture Capital Deal Terms Report (6th Edition, 2009).
} 
One of the most frequently analyzed features of the VC-company contracts is the use of convertible securities that combines the features of equity and debt. A number of studies offer (generally non-mutually exclusive) explanations for its prevalent use. ${ }^{37}$ Berglof (1994) analyzes the potential conflict of interests that arises from a future sale of the company to a third party. On the one hand, an entrepreneur values private benefits of control that are increasing in the firm value and is afraid of a sale that compensates him insufficiently for their loss; on the other hand, a VC is afraid of a premature, 'cheap exit' that results in a poor return on her financial investment, but would be enticing for the entrepreneur to accept. Since one conflict is more likely in good states of the world and another in bad states of the world, convertible securities (either convertible debt or convertible preferred stock) with contingent transfer of control to the vulnerable party emerges as the optimal security that best protects the two initial contracting parties against dilution and expropriation from the future buyer. The findings are consistent with the practice; in the USA, nearly all the VC investments are made with preferred stock, either with conversion feature, or in combination with common stock, so that VCs receive the downside protection of debt in poor states of the world, and the upside potential of equity in good states of the world.

In contrast to Berglof's focus on the allocation of control rights, Schmidt (2003) argues that incentive properties of convertible securities - effort incentives for the entrepreneur and the $\mathrm{VC}$ - are crucial in explaining why they are almost always used in $\mathrm{VC}$ transactions while very rarely used by banks or other outside investors that finance small businesses. He shows that convertible security achieves the first best investment outcomes (relative to standard debt-equity contracts) when the investor's costly effort is important ${ }^{38}$ for the success of the startup; hence, it is used in venture capital finance where extra-financial value of $\mathrm{VC}$ backing is important, but not in bank financing where banks are passive investors.

Hellmann (2006) argues that the key property of convertible preferred stock used in $\mathrm{VC}$ transactions is that it (typically) requires forced conversion of preferred stock to common stock upon IPO exits, but not upon exits by acquisitions. The most commonly used type of convertible preferred stock is participating convertible preferred (PCP), ${ }^{39}$ which allows holders to 'double-dip', i.e., receive both the debt-like payoff (redemption value) and the equity-like payoff (participation value) as long as the security remains unconverted. In most VC contracts, conversion of preferred stock to common is forced ('automatic conversion') rather than voluntary in cases of an exit via an IPO. Thus, PCP with automatic conversion upon IPOs effectively allocates more cash flow rights to VCs in exits via acquisitions than in IPO exits. Hellmann argues that this is optimal in a model with double moral hazard, where both the entrepreneur and the VC provide value-adding effort. In a related paper, Bengtsson (2009) finds that restrictive covenants are more prevalent in contracts with debt-like payoffs (i.e., PCP) as compared to simple convertible preferred that resembles equity more closely. Cumming (2008) also shows

\footnotetext{
${ }^{37}$ Marx (1998), Bergemann and Hege (1998), Trester (1998), Kirilenko (2001), Gilson and Schizer (2003), and Cornelli and Yosha (2003).

${ }^{38}$ Also see Casamatta (2003) and Repullo and Suarez (2004).

${ }^{39}$ See Metrick and Yasuda (2010b, Ch. 9), for different types of preferred stock used in VC transactions.
} 
that stronger $\mathrm{VC}$ control rights are more likely to lead to exits by acquisitions rather than by write-offs or IPOs. ${ }^{40}$

Another feature of VC-company contracts that has drawn significant attention in the literature is that a VC's total investment in a company is often staged over time and followon investments are either implicitly or explicitly conditional on reaching milestones. ${ }^{41}$ Gompers (1995) argues that this contractual feature protects VCs against inefficient continuation of the project by entrepreneurs and thus is most valuable when liquidation values are hurt the most from inefficient continuation, and finds empirical evidence in support of this argument. Specifically, Gompers analyzes a sample of 794 VC-backed companies' investment history and finds that more frequent financing rounds (shorter duration between rounds) are associated with high levels of agency costs (measured by, e.g., the ratio of intangible to total assets, the market-to-book ratio, and R\&D intensity).

Admati and Pfleiderer (1994) also analyze stage financing and show that a fixedfraction contract where the insider $\mathrm{VC}$ always receives a fixed fraction of the equity of the company in all financing rounds induces the inside investor (the initial VC) to make optimal investment decisions. ${ }^{42}$ In a related paper, Fluck et al. (2004) argue that, without syndication, the holdup cost exceeds the efficiency gain of staged financing. While staged financing reduces the agency cost of inefficient continuation of unpromising projects, it gives too much bargaining power to early-stage venture capitalists and leads to dilution of entrepreneurs' stakes ex post, unless staged financing is combined with preagreed syndication of later-stage investments. The results highlight the complementarity of staged financing and syndication, two somewhat distinct features of VC investments.

In another study examining bargaining between VCs and entrepreneurs in staged financing, Inderst et al. (2007) argue that staged financing, combined with the closedfund feature of VC partnerships (whereby the fund size, or the 'depth of the investor's pocket', is fixed) and the fact that a fund finances a portfolio of projects, may lead not only to improved bargaining power for the $\mathrm{VC}$, but also to improved incentives for entrepreneurs. The results suggest that staged financing and the fund structure where multiple portfolio companies compete for a fixed amount of capital are complementary.

Kaplan and Stromberg (2003) analyze actual VC contracts in light of contracting theory and find that $\mathrm{VC}$ contracts allow separate allocations of cash flow rights, board rights, voting rights, liquidation rights, and other control rights among stakeholders. Kaplan and Stromberg (2004) relate expected post-investment actions by VCs to contracts and find that greater $\mathrm{VC}$ control is associated with increased management intervention while greater VC equity incentives are associated with increased valueadding efforts.

Other studies focus on less studied aspects of VC-company contracts. Hellmann (1998) studies why entrepreneurs give up control rights over to $\mathrm{VC}$, exposing them to the risk of being fired before their shares are fully vested. A key ingredient of the model is that entrepreneurs may take non-contractible actions that increase their private benefits of control, while venture capitalists may make non-contractible (and costly) efforts to search for a good management team. Equilibrium conditions are derived where entrepreneurs

\footnotetext{
${ }^{40}$ Also see Cumming and Johan (2008), which find through survey data that, when VCs plan to exit via acquisitions, they obtain stronger control rights and are more likely to use convertible preferred stock as opposed to common stock.

${ }^{41}$ Also see Neher (1999).

${ }^{42}$ Lerner (1994a) provides empirical evidence in support of this hypothesis.
} 
voluntarily relinquish control knowing that venture capitalists are incented to search for a superior outside management team.

Field and Hanka (2001) examine a sample of VC-company contracts with post IPO lockup clauses, which prohibit insiders from selling their shares in the open market for a preset period of time (e.g., 6 months) after the IPO date. Expiration of lockups results in large permanent increases in trading volumes and abnormal negative returns around the lockup expiration date. Broughman and Fried (2010) examine whether cash flow rights are renegotiated between entrepreneurs and VCs by studying sales of Silicon Valley firms. Results suggest VCs sometime concede cash-flow rights and allow common shareholders to receive payment before VCs' liquidation preferences are satisfied, especially when the firm's choice of corporate law gives shareholders more power to hold up the sale.

More recently, researchers have started to examine determinants of both time-series and cross-country variation in contract terms. Inderst and Muller (2004) build an equilibrium model in which capital-market characteristics affect the relative supply and demand for VC capital, which in turn affects bargaining between entrepreneurs and VCs, which in turn affects the valuation and relative ownership shares of VCs and entrepreneurs. The model explains the cyclicality of the VC industry and in particular the Internet boom and bust period in which entrepreneurs enjoyed high valuations and retained large equity shares during the boom, whereas venture capitalists obtained much larger ownership shares and demanded low valuations during the bust.

Several papers empirically study the effects of legal regimes on VC contracts using international data and offer somewhat mixed evidence. ${ }^{43}$ Kaplan et al. (2007) examine features of international $\mathrm{VC}$ contracts and find that legal regimes affect contractual features more when investors are inexperienced, but that more experienced VCs implement US-style contracts regardless of legal regime. Use of US-style contracts is associated with lower failure rates of VC firms, even after controlling for VC experience, suggesting efficiency of US style contracts even in non-US markets. Similarly, Bottazzi et al. (2009) find that the legal system in the target country does not explain contract provisions after controlling for VC home country effects. In contrast, Lerner and Schoar (2005) study international PE contracts (which include both VC and BO investments) and find that, while convertible preferred stock with covenants is the favoured contractual choice in high-enforcement and common law nations, majority equity ownership combined with debt and board control is often used in low-enforcement and civil law nations. They argue that the legal system constrains the ability of private parties to write contracts that are complex or state contingent. Similarly, Balcarcel et al. (2010) find that both capital flows and investment patterns systematically vary with the rule of law variables of the target countries.

\subsection{Contracts between buyout investors and portfolio companies}

Researchers know relatively little about the contractual relationships between buyout investors and portfolio companies, due in part to data limitations that appear to be even

\footnotetext{
${ }^{43}$ Also see Black and Gilson (1998), Allen and Song (2003), Cumming and Johan (2008) and Cao et al. (2010). Cumming and Johan (2006) examine features of international VC and BO partnership agreements and find that both the legal regimes and presence of partners with legal training affect the frequency of use of covenants in such contracts.
} 
more severe for buyouts than those for VC contracts. Here we review a small group of empirical papers that provide evidence suggestive of potential agency conflicts between BO fund managers and investors during hot markets.

In one of the earlier studies examining financial structure and pricing of public-toprivate buyout transactions in the 1980s, Kaplan and Stein (1993) find that, over time, as the junk bond market took off and record amounts were issued, both the buyout investors and the management teams took more money out of transactions up-front.

One distinct contractual difference between the $\mathrm{BO}$ and VC fund managers' compensation is that $\mathrm{BO}$ fund managers routinely charge to their portfolio companies upfront transaction fees at the time of the investment as well as on-going monitoring fees. These fees are distinct from management fees that GPs charge to the investors of the funds, and may be shared with investors and/or used to offset the management fees. Incentive effects of these portfolio company fees are not well understood, though anecdotal evidence suggests that at the height of the latest BO boom of 2003-2007, they comprised a very significant portion of the GPs' total revenues, especially at larger funds.

Metrick and Yasuda (2010a) build a model that estimates expected present values of PE manager fee revenues as functions of the fund fee structure, firm characteristics, and deal structures (such as leverage and the portfolio company fee structure). While the expected values of portfolio company fees (the sum of transaction fees and monitoring fees) are only a third of expected carry when the leverage ratio is $1: 1$, they increase to nearly $90 \%$ of expected carry when the leverage ratio is increased to $4: 1{ }^{44}$ As these fees are less risky and less sensitive to performance than carried interest, larger portfolio company fees associated with higher leverage suggests that leverage might weaken monitoring incentives of $\mathrm{BO}$ fund managers to maximize firm value and earn carry.

Using a sample of 1,157 buyout transactions from 1980 to 2008, Axelson et al. (2010) show that the economy-wide cost of borrowing rather than industry-specific characteristics is the main driver of the buyout leverage [also see Brinkhuis and De Maeseneire (2009) for similar findings using a sample of European buyouts]. Credit market conditions also have a strong effect on prices paid in buyouts, and moreover use of high leverage in transactions negatively affects fund performance. Combined with the results of Kaplan and Stein (1993) and Metrick and Yasuda (2010a), these findings suggest that agency problems between buyout fund mangers and their investors may be exacerbated when cheap debt is available and allows fund managers to pocket large fees upfront. Clearly more research is needed to understand contractual patterns in BO transactions.

\section{Conclusion}

$\mathrm{VC}$ and $\mathrm{BO}$ funds are financial intermediaries that invest in private companies, take an active role in monitoring and advising investee companies, exit investments through a sale or an IPO, and whose goal is to maximise present values of their current and future fund revenues (earned via management fees and carried interest). VCs are specialists whose superior screening capability for high-growth, risky start-up firms in high-tech sectors helps alleviate the underinvestment problem that arises from the severe information

\footnotetext{
${ }^{44}$ Leverage directly impacts relative values of portfolio company fees, because these fees are paid as a percentage of the total enterprise value of the firm, whereas BO funds invest only in the equity portions of the firm's capital structure.
} 
asymmetry between informed entrepreneurs and uninformed investors. In contrast, economic rationale for $\mathrm{BO}$ specialists, especially those that are engaged primarily in private-to-private transactions and do not require high leverage, is not well understood. More research is needed to improve our understanding of how generic $\mathrm{BO}$ funds emerge in the economy. Both $\mathrm{VC}$ and BO-backing is associated with significant changes in the ways the investee companies are operated, including more independent and hands-on boards, higher earnings quality, and higher CEO turnover.

Evidence on existence of excess performance (and its persistence) in private equity is mixed. This is due in part to significant data limitations and methodological challenges that arise as results of the data limitations. Naïve applications of standard approaches to asset pricing tend to produce overestimates of alphas and underestimates of market beta. Valiant attempts have been made to correct for various aspects of data problems, including stale prices, infrequency of return realizations, sample selection, and missing observations, especially in the VC literature where data availability is better and the literature dates back longer. In comparison, the literature on BO performance is less well developed and provides excellent opportunities for new research.

As VCs are thought to emerge as solutions to the underinvestment problem arising from information asymmetry between entrepreneurs and uninformed investors, it is natural that contracts used in VC transactions have features that address many potential agency problems. The literature has analyzed, among other features, use of convertible securities, staged financing, and syndication. The use of leverage as a disciplinary device to constrain the use of excess cash is emphasized as the economic rationale of leveraged buyouts, but the economic purpose of non-leveraged buyout transactions is not well established: the contract (and other economic) mechanisms that address agency issues in these non-leveraged transactions remain an open question. Finally, contracts between VC and BO fund managers (GPs) and their investors (LPs) also address various agency issues. Since LPs do not monitor GPs on the day-to-day basis, their contracts are designed to best align their interests, via use of a profit-sharing agreement (carried interest), closedend, finite-life fund structure, limited reinvestments, and explicit negative covenants preventing GPs from taking excessive risk and/or diverting efforts away from funds. Recent studies suggest that these features of contracts between LPs and GPs dynamically affect fund performance and performance persistence. Improving our understanding of the interactions between GP incentives (that are determined by the fund structure) and fund performance is another fruitful area for future research.

\section{References}

Acharya, V. V. and Johnson, T. C., 'More insiders, more insider trading: evidence from private equity buyouts', Journal of Financial Economics, forthcoming.

Acharya, V. V., Kehoe, C. and Reyner, M., 'Private equity vs. PLC boards in the UK: a comparison of practices and effectiveness', Journal of Applied Corporate Finance, Vol. 21 no. 1, Winter 2009, pp. $45-56$.

Admati, A. R. and Pfleiderer, P., 'Robust financial contracting and the role of venture capitalists', Journal of Finance, Vol. 49 no. 2, Jun, 1994, pp. 371-402.

Allen, F. and Song, W., 'Venture capital and corporate governance', in P. Cornelius and B. Kogut, eds, Corporate Governance and Capital Flows in a Global Economy (Oxford University Press, 2003), pp. 133-56.

Andrade, G. M. and Kaplan, S. N., 'How costly is financial (not economic) distress? Evidence from highly leveraged transactions that became distressed', Journal of Finance, Vol. 53 no. 5, 1998, pp. 1443-93. 
Asness, C., Krail, R. and Liew, J., 'Do hedge funds hedge?', The Journal of Portfolio Management, Vol. 28 no. 6-19, 2001.

Axelson, U., Jenkinson, T., Stromberg, P. J. and Weisbach, M. S., 'Borrow cheap, buy high? The determinants of leverage and pricing in buyouts', Working Paper (Fisher College of Business, 2010).

Axelson, U., Stromberg, P. and Weisbach, M. S., 'Why are buyouts levered? The financial structure of private equity funds', Journal of Finance, Vol. 64 no. 4, Aug, 2009, pp. 1549-82.

Baker, G. P. and Wruck, K. H., 'Organizational changes and value creation in leveraged buyouts: the case of the O. M. Scott \& Sons Company', Journal of Financial Economics, Vol. 25 no. 2, Dec, 1989, pp. 163-90.

Baker, M. and Gompers, P. A., 'The determinants of board structure at the initial public offering', Journal of Law \& Economics, Vol. 46 no. 2, Oct, 2003, pp. 569-98.

Balcarcel, A., Hertzel, M. and Lindsey, L., 'Contracting frictions and cross-border capital flows: evidence from venture capital', Working Paper (Arizona State University, 2010).

Barber, B. and Yasuda, A., 'Risk-adjusted returns in the venture capital and buyout industry', Working Paper (UC Davis, 2010).

Barry, C. B., Muscarella, C. J., Peavy, J. W. and Vetsuypens, M. R., 'The role of venture capital in the creation of public companies: evidence from the going-public process', Journal of Financial Economics, Vol. 27 no. 2, Oct, 1990, pp. 447-71.

Bayar, O. and Chemmanur, T. J., 'IPOs versus acquisitions and the valuation premium puzzle: a theory of exit choice by entrepreneurs and venture capitalists', Journal of Financial and Quantitative Analysis, forthcoming, 2010.

Bengtsson, O., 'Restrictive covenants in venture capital contracts', Working Paper (University of Illinois at Urbana-Champaign, 2009).

Bergemann, D. and Hege, U., 'Venture capital financing, moral hazard, and learning', Journal of Banking \& Finance, Vol. 22 no. 6-8, Aug, 1998, pp. 703-35.

Berglof, E., 'A control-theory of venture capital finance', Journal of Law Economics \& Organization, Vol. 10 no. 2, Oct, 1994, pp. 247-67.

Bernstein, S., Lerner, J., Sorensen, M. and Stromberg, P. J., 'Private equity and industry performance', Working Paper (Harvard Business School, 2010).

Bharath, S. T. and Dittmar, A. K., 'Why do firms use private equity to opt out of public markets?', Review of Financial Studies, Vol. 23 no. 5, May, 2010, pp. 1771-818.

Black, B. S. and Gilson, R. J., 'Venture capital and the structure of capital markets: banks versus stock markets', Journal of Financial Economics, Vol. 47 no. 3, Mar, 1998, pp. 243-77.

Boone, A. L. and Mulherin, J. H., 'Do private equity consortiums facilitate collusion in takeover bidding?', Working Paper (University of Kansas, 2009).

Bottazzi, L., Da Rin, M. and Hellmann, T., 'Who are the active investors? Evidence from venture capital', Journal of Financial Economics, Vol. 89 no. 3, Sep, 2008, pp. 488-512.

Bottazzi, L., Da Rin, M. and Hellmann, T., 'What is the role of legal systems in financial intermediation? Theory and evidence', Journal of Financial Intermediation, Vol. 18 no. 4, Oct, 2009, pp. 559-98.

Brav, A. and Gompers, P. A., 'Myth or reality? The long-run underperformance of initial public offerings: evidence from venture and nonventure capital-backed companies', Journal of Finance, Vol. 52 no. 5, Dec, 1997, pp. 1791-821.

Brinkhuis, S. and De Maeseneire, W., 'What drives leverage in leveraged buyouts? An analysis of European LBOs' capital structure', Working Paper (Erasmus School of Economics, 2009).

Broughman, B. and Fried, J., 'Renegotiation of cash flow rights in the sale of VC-backed firms', Journal of Financial Economics, Vol. 95 no. 3, Mar, 2010, pp. 384-99.

Brown, D. T., Fee, C. E. and Thomas, S. E., 'Financial leverage and bargaining power with suppliers: evidence from leveraged buyouts', Journal of Corporate Finance, Vol. 15 no. 2, Apr, 2009, pp. 196-211.

Campello, M. and Da Matta, R., 'How are venture capitalists rewarded? The economics of venture capital partnerships', Working Paper (University of Illinois at Urbana-Champaign, 2010).

Cao, J., Cumming, D. J., Qian, M. and Wang, X., 'Creditor rights and LBOs', Working Paper (Singapore Management University, 2010). 
Cao, J. and Lerner, J., 'The performance of reverse leveraged buyouts', Journal of Financial Economics, Vol. 91 no. 2, Feb, 2009, pp. 139-57.

Casamatta, C., 'Financing and advising: optimal financial contracts with venture capitalists', Journal of Finance, Vol. 58 no. 5, Oct, 2003, pp. 2059-85.

Caselli, S., Gatti, S. and Perrini, F., 'Are venture capitalists a catalyst for innovation?', European Financial Management, Vol. 15 no. 1, Jan, 2009, pp. 92-111.

Chan, Y. S., 'On the positive role of financial intermediation in allocation of venture capital in a market with imperfect information', Journal of Finance, Vol. 38 no. 5, 1983, pp. 1543-68.

Chemmanur, T. J., 'Venture capital, private equity, IPOs, and banking: an introduction and agenda for future research', Journal of Economics and Business, forthcoming, 2010.

Chen, H., Gompers, P., Kovner, A. and Lerner, J., 'Buy local? The geography of venture capital', Journal of Urban Economics, Vol. 67 no. 1, Jan, 2010, pp. 90-102.

Choi, W., Metrick, A., and Yasuda, A., 'A Model of Private Equity Fund Compensation', Working Paper (Yale School of Management, 2011).

Chung, J.-W., 'Leveraged buyouts of private companies', Working Paper (The Chinese University of Hong Kong, 2009).

Chung, J.-W., Sensoy, B. A., Stern, L. H. and Weisbach, M. S., 'Incentives of private equity general partners from future fundraising', Working Paper (Ohio State University, 2010).

Cochrane, J. H., 'The risk and return of venture capital', Journal of Financial Economics, Vol. 75 no. 1, Jan, 2005, pp. 3-52.

Cornelli, F. and Karakas, O., 'Private equity and corporate governance: do LBOs have more effective boards?‘, Working Paper (London Business School, 2008).

Cornelli, F., Kominek, Z. and Ljungqvist, A., 'Monitoring managers: does it matter?', Working Paper (New York University, 2010).

Cornelli, F. and Yosha, O., 'Stage financing and the role of convertible securities', Review of Economic Studies, Vol. 70 no. 1, Jan, 2003, pp. 1-32.

Cotter, J. F. and Peck, S. W., 'The structure of debt and active equity investors: the case of the buyout specialist', Journal of Financial Economics, Vol. 59 no. 1, Jan, 2001, pp. 101-47.

Cumming, D., 'Contracts and exits in venture capital finance', Review of Financial Studies, Vol. 21 no. 5, Sep, 2008, pp. 1947-82.

Cumming, D. and Johan, S., 'Is it the law or the lawyers? investment covenants around the world', European Financial Management, Vol. 12 no.4, 2006, pp.535-574.

Cumming, D., and Johan, S., 'Preplanned exit strategies in venture capital', European Economic Review, Vol. 52, 2008, pp.1209-41.

Cumming, D., Siegel, D. S. and Wright, M., 'Private equity, leveraged buyouts and governance', Journal of Corporate Finance, Vol. 13 no. 4, Sep, 2007, pp. 439-60.

Davis, S. J., Haltiwanger, J. C., Jarmin, R. S., Lerner, J. and Miranda, J., 'Private equity and employment', Working Paper (US Census Bureau Center for Economic Studies, 2008).

DeAngelo, H. and DeAngelo, L., 'Management buyouts of publicly traded corporations', Financial Analysts Journal, Vol. 43 no. 3, 1987, pp. 38-49.

DeAngelo, H., DeAngelo, L. and Rice, E. M., 'Going private: minority freezeouts and stockholder wealth', Journal of Law \& Economics, Vol. 27 no. 2, 1984, pp. 367-401.

Degeorge, F. and Zeckhauser, R., 'The reverse LBO decision and firm performance: theory and evidence', Journal of Finance, Vol. 48 no. 4, Sep, 1993, pp. 1323-48.

Demiroglu, C. and James, C. M., 'The role of private equity group reputation in LBO financing', Journal of Financial Economics, Vol. 96 no. 2, May, 2010, pp. 306-30.

Denis, D. J., 'Corporate-investment decisions and corporate-control: evidence from going-private transactions', Financial Management, Vol. 21 no. 3, Fal, 1992, pp. 80-94.

Denis, D. J., 'Organizational form and the consequences of highly leveraged transactions: Kroger's recapitalization and Safeway's LBO', Journal of Financial Economics, Vol. 36 no. 2, Oct, 1994, pp. 193-224.

Denis, D. J., 'Entrepreneurial finance: an overview of the issues and evidence', Journal of Corporate Finance, Vol. 10 no. 2, Mar, 2004, pp. 301-26. 
Diller, C. and Kaserer, C., 'What drives private equity returns? Fund inflows, skilled GPs, and/or risk?', European Financial Management, Vol. 15 no. 3, Jun, 2009, pp. 643-75.

Driessen, J., Phalippou, L. and Lin, T.-C., 'A new method to estimate risk and return of non-traded assets from cash flows: the case of private equity funds', Working Paper (University of Amsterdam, 2009).

Fang, L. H., Ivashina, V. and Lerner, J., 'Unstable equity? Combining banking with private equity investing', Working Paper (Harvard Business School 2010).

Fenn, G. W. and Liang, N., 'New resources and new ideas: private equity for small businesses', Journal of Banking \& Finance, Vol. 22 no. 6-8, Aug, 1998, pp. 1077-84.

Field, L. C. and Hanka, G., 'The expiration of IPO share lockups', Journal of Finance, Vol. 56 no. 2 , Apr, 2001, pp. 471-500.

Fluck, Z., Garrison, K. R. and Myers, S. C., 'Venture capital: an experiment in computational corporate finance', Working Paper (MIT, 2004).

Gilson, R. and Schizer, D., 'Understanding venture capital structure: a tax explanation for convertible preferred stock', Harvard Law Review, Vol. 116 no.3, Jan, 2003, pp. 874-916.

Gompers, P., 'The rise and fall of venture capital', Business and Economic History, Vol. 23 no. 2, 1994, pp. 1-24.

Gompers, P., Kovner, A. and Lerner, J., 'Specialization and success: evidence from venture capital', Journal of Economics \& Management Strategy, Vol. 18 no. 3, Fal, 2009, pp. 817-44.

Gompers, P., Kovner, A., Lerner, J. and Scharfstein, D., 'Venture capital investment cycles: the impact of public markets', Journal of Financial Economics, Vol. 87 no. 1, Jan, 2008, pp. 1-23.

Gompers, P., Kovner, A., Lerner, J. and Scharfstein, D., 'Performance persistence in entrepreneurship', Journal of Financial Economics, Vol. 96 no. 1, Apr, 2010, pp. 18-32.

Gompers, P. and Lerner, J., 'Risk and reward in private equity investments: the challenge of performance assessment', Journal of Private Equity, Vol. 1, 1997, pp. 5-12.

Gompers, P. and Lerner, J., 'Venture capital distributions: short-run and long-run reactions', Journal of Finance, Vol. 53 no. 6, Dec, 1998a, pp. 2161-83.

Gompers, P. and Lerner, J., 'An analysis of compensation in the US venture capital partnership', Journal of Financial Economics, Vol. 51 no. 1, Jan, 1999a, pp. 3-44.

Gompers, P. and Lerner, J., 'Conflict of interest in the issuance of public securities: evidence from venture capital', Journal of Law \& Economics, Vol. 42 no. 1, Apr, 1999b, pp. 1-28.

Gompers, P. and Lerner, J., 'Money chasing deals? The impact of fund inflows on private equity valuations', Journal of Financial Economics, Vol. 55 no. 2, Feb, 2000, pp. 281-325.

Gompers, P. and Lerner, J., 'The venture capital revolution', Journal of Economic Perspectives, Vol. 15 no. 2, Spr, 2001, pp. 145-68.

Gompers, P., Lerner, J. and Scharfstein, D., 'Entrepreneurial spawning: public corporations and the genesis of new ventures, 1986 to 1999', Journal of Finance, Vol. 60 no. 2, Apr, 2005, pp. 577-614.

Gompers, P.A., 'Optimal investment, monitoring, and the staging of venture capital', Journal of Finance, Vol. 50 no. 5, Dec, 1995, pp. 1461-89.

Gompers, P.A., 'Grandstanding in the venture capital industry', Journal of Financial Economics, Vol. 42 no. 1, Sep, 1996, pp. 133-56.

Gompers, P.A., 'Venture capital growing pains: should the market diet?', Journal of Banking \& Finance, Vol. 22 no. 6-8, Aug, 1998, pp. 1089-104.

Gompers, P.A. and Lerner, J., 'What drives venture capital fundraising', Brookings Papers on Economic Activity, 1998b, pp. 149-204.

Gompers, P.A. and Xuan, Y., 'Bridge Building in Venture Capital-Backed Acquisitions', Working Paper (Harvard Business School, 2009).

Gorman, M. and Sahlman, W. A., 'What do venture capitalists do', Journal of Business Venturing, Vol. 4 no. 4, Jul, 1989, pp. 231-48.

Groh, A. P. and Gottschalg, O., 'The opportunity cost of capital of US buyouts', Working Paper (IESE Business School, 2009).

Guo, S., Hotchkiss, E. S. and Song, W., 'Do buyouts (still) create value', Journal of Finance, Vol. 66 no. 2, Apr, 2011, pp. 479-517. 
Gupta, A. and Rosenthal, L., 'Ownership structure, leverage, and firm value: the case of leveraged recapitalizations', Financial Management, Vol. 20 no. 3, 1991, pp. 69-83.

Hamao, Y., Packer, F. and Ritter, J. R., 'Institutional affiliation and the role of venture capital: evidence from initial public offerings in Japan', Pacific-Basin Finance Journal, Vol. 8 no. 5, 2000, pp. 529-58.

Harris, R., Siegel, D. S. and Wright, M., 'Assessing the impact of management buyouts on economic efficiency: plant-level evidence from the United Kingdom', Review of Economics and Statistics, Vol. 87 no. 1, Feb, 2005, pp. 148-53.

Hellmann, T., 'The allocation of control rights in venture capital contracts', Rand Journal of Economics, Vol. 29 no. 1, Spr, 1998, pp. 57-76.

Hellmann, T., 'IPOs, acquisitions, and the use of convertible securities in venture capital', Journal of Financial Economics, Vol. 81 no. 3, Sep, 2006, pp. 649-79.

Hellmann, T., Lindsey, L. and Puri, M., 'Building relationships early: banks in venture capital', Review of Financial Studies, Vol. 21 no. 2, Apr, 2008, pp. 513-41.

Hellmann, T. and Puri, M., 'The interaction between product market and financing strategy: the role of venture capital', Review of Financial Studies, Vol. 13 no. 4, Win, 2000, pp. 959-84.

Hellmann, T. and Puri, M., 'Venture capital and the professionalization of start-up firms: empirical evidence', Journal of Finance, Vol. 57 no. 1, Feb, 2002, pp. 169-97.

Hite, G. L. and Vetsuypens, M. R., 'Management buyouts of divisions and shareholder wealth', Journal of Finance, Vol. 44 no. 4, Sep, 1989, pp. 953-70.

Hochberg, Y. V., 'Venture Capital and corporate governance in the newly public firm', Working Paper (Northwestern University, 2003).

Hochberg, Y. V., Ljungqvist, A. and Lu, Y., 'Whom you know matters: venture capital networks and investment performance', Journal of Finance, Vol. 62 no. 1, Feb, 2007, pp. 251-301.

Hochberg, Y. V., Ljungqvist, A. and Lu, Y., 'Networking as a barrier to entry and the competitive supply of venture capital', Journal of Finance, Vol. 65 no. 3, 2010a, pp. 829-59.

Hochberg, Y. V., Ljungqvist, A. and Vissing-Jorgensen, A., 'Informational hold-up and performance persistence in venture capital', Working Paper (New York University, 2010b).

Holthausen, R. W. and Larcker, D. F., 'The financial performance of reverse leveraged buyouts', Journal of Financial Economics, Vol. 42 no. 3, Nov, 1996, pp. 293-332.

Hsu, D. H., 'What do entrepreneurs pay for venture capital affiliation?', Journal of Finance, Vol. 59 no. 4, Aug, 2004, pp. 1805-44.

Inderst, R. and Mueller, H. M., 'Early-stage financing and firm growth in new industries', Journal of Financial Economics, Vol. 93 no. 2, Aug, 2009, pp. 276-91.

Inderst, R., Mueller, H. M. and Munnich, F., 'Financing a portfolio of projects', Review of Financial Studies, Vol. 20 no. 4, Jul, 2007, pp. 1289-325.

Inderst, R. and Muller, H. M., 'The effect of capital market characteristics on the value of start-up firms', Journal of Financial Economics, Vol. 72 no. 2, May, 2004, pp. 319-56.

Ivashina, V. and Kovner, A., 'The private equity advantage: leveraged buyout firms and relationship banking', Working Paper (Harvard Business School, 2010).

Jensen, M. C., 'Agency costs of free cash flow, corporate-finance, and takeovers', American Economic Review, Vol. 76 no. 2, May, 1986, pp. 323-29.

Jensen, M. C., 'Eclipse of the public corporation', Harvard Business Review, Vol. 67 no. 5, Sep-Oct, 1989, pp. 61-74.

Jensen, M. C., 'The economic case for private equity (and some concerns)', Working Paper (Harvard University 2007).

Jensen, M. C. and Meckling, W. H., 'Theory of firm: managerial behavior, agency costs and ownership structure', Journal of Financial Economics, Vol. 3 no. 4, 1976, pp. 305-60.

Jones, C. M. and Rhodes-Kropf, M., 'The price of diversifiable risk in venture capital and private equity', Working Paper (Columbia Business School 2003).

Kaplan, S., 'Management buyouts: evidence on taxes as a source of value', Journal of Finance, Vol. 44 no. 3, Jul, 1989a, pp. 611-32.

Kaplan, S., 'The effects of management buyouts on operating performance and value', Journal of Financial Economics, Vol. 24 no. 2, Oct, 1989b, pp. 217-54. 
Kaplan, S. N., 'The staying power of leveraged buyouts', Journal of Financial Economics, Vol. 29 no. 2, Oct, 1991, pp. 287-313.

Kaplan, S. N., Klebanov, M. M. and Sorensen, M., 'Which CEO characteristics and abilities matter?', Journal of Finance, forthcoming, 2010.

Kaplan, S. N. and Lerner, J., 'It ain't broke: the past, present, and future of venture capital', Journal of Applied Corporate Finance, Vol. 22 no. 2, 2010, pp. 36-47.

Kaplan, S. N., Martel, F. and Stromberg, P., 'How do legal differences and experience affect financial contracts?', Journal of Financial Intermediation, Vol. 16 no. 3, Jul, 2007, pp. 273-311.

Kaplan, S. N. and Schoar, A., 'Private equity performance: returns, persistence, and capital flows', Journal of Finance, Vol. 60 no. 4, Aug, 2005, pp. 1791-823.

Kaplan, S. N., Sensoy, B. A. and Stromberg, P., 'Should investors bet on the jockey or the horse? Evidence from the evolution of firms from early business plans to public companies', Journal of Finance, Vol. 64 no. 1, Feb, 2009, pp. 75-115.

Kaplan, S. N., Sensoy, B. A. and Stromberg, P. J., 'How well do venture capital databases reflect actual investments?', Working Paper (University of Chicago, 2002).

Kaplan, S. N. and Stein, J. C., 'How risky is the debt in highly leveraged transactions?', Journal of Financial Economics, Vol. 27 no. 1, 1990, pp. 215-45.

Kaplan, S. N. and Stein, J. C., 'The evolution of buyout pricing and financial structure in the 1980s', Quarterly Journal of Economics, Vol. 108 no. 2, May, 1993, pp. 313-57.

Kaplan, S. N. and Stromberg, P., 'Financial contracting theory meets the real world: an empirical analysis of venture capital contracts', Review of Economic Studies, Vol. 70 no. 2, Apr, 2003, pp. 281-315.

Kaplan, S. N. and Stromberg, P., 'Characteristics, contracts, and actions: evidence from venture capitalist analyses', Journal of Finance, Vol. 59 no. 5, Oct, 2004, pp. 2177-210.

Kaplan, S. N. and Stromberg, P., 'Leveraged buyouts and private equity', Journal of Economic Perspectives, Vol. 23 no. 1, Win, 2009, pp. 121-46.

Kaplan, S. N. and Stromberg, P. J., 'Venture capitalists as principals: contracting, screening, and monitoring', Working Paper (University of Chicago, 2001).

Katz, S. P., 'Earnings quality and ownership structure: the role of private equity sponsors', Accounting Review, Vol. 84 no. 3, May, 2009, pp. 623-58.

Kirilenko, A. A., 'Valuation and control in venture finance', Journal of Finance, Vol. 56 no. 2, Apr, 2001, pp. 565-87.

Korteweg, A. G. and Sorensen, M., 'Risk and return characteristics of venture capital-backed entrepreneurial companies', Review of Financial Studies, Vol. 23 no. 10, 2010, pp. 3738-3772.

Kortum, S. and Lerner, J., 'Assessing the contribution of venture capital to innovation', Rand Journal of Economics, Vol. 31 no. 4, Win, 2000, pp. 674-92.

Kracaw, W. A. and Zenner, M., 'The wealth effects of bank financing announcements in highly leveraged transactions', Journal of Finance, Vol. 51 no. 5, Dec, 1996, pp. 1931-46.

Krishnan, C. N. V., Ivanov, V., Masulis, R. W. and Singh, A. K., 'Venture capital reputation, postIPO performance and corporate governance', Journal of Financial and Quantitative Analysis, forthcoming, 2011.

Krishnan, C. N. V. and Masulis, R. W., 'Venture capital reputation: a survey', in D. Cumming, ed., The Handbook of Entrepreneurial Finance, Venture Capital and Private Equity (Oxford University Press, forthcoming, 2011).

Lehn, K., Netter, J. and Poulsen, A., 'Consolidating corporate-control: dual-class recapitalizations versus leveraged buyouts', Journal of Financial Economics, Vol. 27 no. 2, Oct, 1990, pp. 557-80.

Lehn, K. and Poulsen, A., 'Free cash flow and stockholder gains in going private transactions', Journal of Finance, Vol. 44 no. 3, Jul, 1989, pp. 771-87.

Lerner, J., 'The syndication of venture capital investments', Financial Management, Vol. 23 no. 3, Fal, 1994a, pp. 16-27.

Lerner, J., 'Venture capitalists and the decision to go public', Journal of Financial Economics, Vol. 35 no. 3, Jun, 1994b, pp. 293-316. 
Lerner, J., 'Venture capitalists and the oversight of private firms', Journal of Finance, Vol. 50 no. 1, Mar, 1995, pp. 301-18.

Lerner, J., 'The future of private equity', European Financial Management, Vol. 17 no. 3, Jun, 2011.

Lerner, J. and Schoar, A., 'The illiquidity puzzle: theory and evidence from private equity', Journal of Financial Economics, Vol. 72 no. 1, Apr, 2004, pp. 3-40.

Lerner, J. and Schoar, A., 'Does legal enforcement affect financial transactions? The contractual channel in private equity', Quarterly Journal of Economics, Vol. 120 no. 1, Feb, 2005, pp. 223-46.

Lerner, J., Schoar, A. and Wongsunwai, W., 'Smart institutions, foolish choices: the limited partner performance puzzle', Journal of Finance, Vol. 62 no. 2, Apr, 2007, pp. 731-64.

Lerner, J., Sorensen, M. and Stromberg, P. J., 'Private equity and long-run investment: the case of innovation', Journal of Finance, Vol. 66, no. 2, April 2011, 445-477.

Li, X. and Masulis, R. W., 'Venture capital investments by IPO underwriters: certification, alignment of interest or moral hazard?', Working Paper (Australian School of Business, University of New South Wales, 2004).

Lichtenberg, F. R. and Siegel, D., 'The effect of ownership changes on the employment and wages of central office and other personnel', Journal of Law \& Economics, Vol. 33 no. 2, Oct, 1990, pp. 383-408.

Lindsey, L., 'Blurring firm boundaries: the role of venture capital in strategic alliances', Journal of Finance, Vol. 63 no. 3, Jun, 2008, pp. 1137-68.

Ljungqvist, A. and Richardson, M. P., 'The cash flow, return and risk characteristics of private equity', Working Paper (New York University, 2003).

Ljungqvist, A., Richardson, M. P. and Wolfenzon, D., 'The investment behavior of buyout funds: theory and evidence', Working Paper (New York University, 2007).

Long, W. F. and Ravenscraft, D. J., 'LBOs, debt and R\&D intensity', Strategic Management Journal, Vol. 14, Sum, 1993, pp. 119-35.

Lopez de Silanes, F., Phalippou, L. and Gottschalg, O., 'Giants at the gate: diseconomies of scale in private equity', Working Paper (University of Amsterdam, 2010).

Maats, F., Metrick, A., Yasuda, A., Hinkes, B. and Vershovski, S., 'On the consistency and reliability of venture capital databases', Working Paper (Yale School of Management, 2010).

Marquez, R. and Singh, R., 'The economics of club bidding in private equity', Working Paper (Boston University, 2010).

Marquez, R. S., Nanda, V. K. and Yavuz, M. D., 'Private equity fund returns: do managers actually leave money on the table?', Working Paper (Washington University in St. Louis, 2010).

Marx, L. M., 'Efficient venture capital financing combining debt and equity', Review of Economic Design, Vol. 3 no. 4, 1998, pp. 371-87.

Masulis, R. W. and Nahata, R., 'Venture capital conflicts of interest: evidence from acquisitions of venture backed firms', Journal of Financial and Quantitative Analysis, forthcoming, 2011.

Masulis, R. W. and Thomas, R. S., 'Does private equity create wealth? The effects of private equity and derivatives on corporate governance', University of Chicago Law Review, Vol. 76 no. 1, Win, 2009, pp. 219-59.

Mehran, H. and Peristiani, S., 'Financial visibility and the decision to go private', Review of Financial Studies, Vol. 23 no. 2, Feb, 2010, pp. 519-47.

Metrick, A. and Yasuda, A., 'The economics of private equity funds', Review of Financial Studies, Vol. 23 no. 6, Jun, 2010a, pp. 2303-41.

Metrick, A. and Yasuda, A., Venture Capital and the Finance of Innovation (John Wiley \& Sons, 2010b).

Muscarella, C. J. and Vetsuypens, M. R., 'Efficiency and organizational-structure: a study of reverse LBOs', Journal of Finance, Vol. 45 no. 5, Dec, 1990, pp. 1389-413.

Nahata, R., 'Venture capital reputation and investment performance', Journal of Financial Economics, Vol. 90 no. 2, Nov, 2008, pp. 127-51.

Neher, D. V., 'Staged financing: an agency perspective', Review of Economic Studies, Vol. 66 no. 2, Apr, 1999, pp. 255-74. 
Officer, M. S., Ozbas, O. and Sensoy, B. A., 'Club deals in leveraged buyouts', Journal of Financial Economics, Vol. 98 no. 2, 2010, pp. 214-40.

Opler, T. and Titman, S., 'The determinants of leveraged buyout activity: free cash flow vs financial distress costs', Journal of Finance, Vol. 48 no. 5, Dec, 1993, pp. 1985-99.

Phalippou, L., 'Beware of venturing into private equity', Journal of Economic Perspectives, Vol. 23 no. 1, Win, 2009, pp. 147-66.

Phalippou, L., 'Venture capital funds: flow-performance relationship and performance persistence', Journal of Banking \& Finance, Vol. 34 no. 3, Mar, 2010, pp. 568-77.

Phalippou, L. and Gottschalg, O., 'The performance of private equity funds', Review of Financial Studies, Vol. 22 no. 4, Apr, 2009, pp. 1747-76.

Povel, P. and Singh, R., 'Stapled finance', Journal of Finance, Vol. 65 no. 3, Jun, 2010, pp. 927-53.

Puri, M. and Zarutskie, R., 'On the lifecycle dynamics of venture-capital- and non-venture-capitalfinanced firms', Working Paper (Duke University, 2010).

Repullo, R. and Suarez, J., 'Venture Capital: A security design approach', Review of Finance, Vol. 8, 2004, pp. 75-108.

Sahlman, W. A., 'The structure and governance of venture-capital organizations', Journal of Financial Economics, Vol. 27 no. 2, Oct, 1990, pp. 473-521.

Schmidt, K. M., 'Convertible securities and venture capital finance', Journal of Finance, Vol. 58 no. 3, Jun, 2003, pp. 1139-66.

Slovin, M. B., Sushka, M. E. and Bendeck, Y. M., 'The intraindustry effects of going-private transactions', Journal of Finance, Vol. 46 no. 4, Sep, 1991, pp. 1537-50.

Sorensen, M., 'How smart is smart money? A two-sided matching model of venture capital', Journal of Finance, Vol. 62 no. 6, Dec, 2007, pp. 2725-62.

Stromberg, P., 'The new demography of private equity', Working Paper (Stockholm School of Economics, 2007).

TheCityUK, 'Private equity 2010', (TheCityUK, 2010).

Tian, X. and Wang, T. Y., 'Tolerance for failure and corporate innovation', Working Paper (University of Minnesota, 2010).

Trester, J. J., 'Venture capital contracting under asymmetric information', Journal of Banking \& Finance, Vol. 22 no. 6-8, Aug, 1998, pp. 675-99.

Ueda, M., 'Banks versus venture capital: Project evaluation, screening, and expropriation', Journal of Finance, Vol. 59 no. 2, Apr, 2004, pp. 601-21.

Wieland, M. F. G., 'The role of human capital in private equity firms' investment strategies', Department of Finance (Erasmus University Rotterdam, ESE, 2009).

Winton, A. and Yerramilli, V., 'Entrepreneurial finance: Banks versus venture capital', Journal of Financial Economics, Vol. 88 no. 1, Apr, 2008, pp. 51-79.

Woodward, S. E., 'Measuring risk for venture capital and private equity portfolios', Working Paper (Sand Hill Econometrics, 2009).

Zarutskie, R., 'The role of top management team human capital in venture capital markets: evidence from first-time funds', Journal of Business Venturing, Vol. 25 no. 1, Jan, 2010, pp. 155-72. 